\title{
Estimation of Benefits from Demonstrating Advanced Wet/Dry Cooling Technology: A Framework and Partial Analysis
}

by

J. W. Currie

T. J. Foley

September 1977

Prepared for the Energy Research and Development Administration under Contract EY-76-C-06-1830 
NOTICE

This report was prepared as an account of work sponsored by the United States Government. Neither the United States nor the Energy Research and Development Administration, nor any of their employees, nor any of their contractors, subcontractors, or their employees, makes any warranty, express or implied, or assumes any legal liability or responsibility for the accuracy, completeness or usefulness of any information, apparatus, product or process disclosed, or represents that its use would not infringe privately owned rights.

The views, opinions and conclusions contained in this report are those of the contractor and do not necessarily represent those of the United States Government or the United States Energy Research and Development Administration.

PACIFIC NORTHWEST LABORATORY

operated by

BATTELLE

for the

ENERGY RESEARCH AND DEVELOPMENT ADMINISTRATION

Under Contract EY-76-C-06-1830

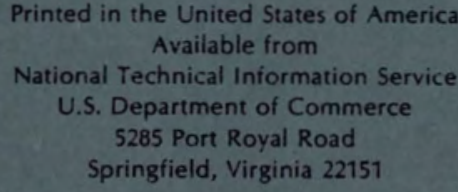

*Pages

D01-025

026-050

051-075

076-100

101-125

126-150

151-175

176-200

201-225

226-250

251-275

276-300
NTIS

Selling Price

$\$ 4.50$

$\$ 5.00$

$\$ 5.50$

$\$ 6.00$

$\$ 6.50$

$\$ 7.00$

57.75

$\$ 8.50$

$\$ 8.75$

$\$ 9.00$

$\$ 10.00$

$\$ 10.25$ 
BNWL -2182

UC- 12

ESTIMATION OF BENEFITS

FROM DEMONSTRATING

ADVANCED WET/DRY COOLING TECHNOLOGY:

A FRAMEWORK AND PARTIAL ANALYSIS

by

J. W. Currie

T. J. Foley

September 1977

BATTELLE

Pacific Northwest Laboratories

Richland, Washington 99352 
- If commercialization of ammonia cooling could be achieved only by a public investment in demonstration, the expected gross benefits from the demonstration are estimated to be $\$ 71$ million for 50 percent wet systems and $\$ 98$ million for 20 percent wet systems.

The estimated benefits varied significantly, depending on whether or not the occurrence of ammonia cooling without public participation in a demonstration is assumed. Hence, rigorous investigation of the hypothesis that some form of advanced wet/dry cooling will be commercialized in the absence of a publicly-funded demonstration is recommended. This should provide important information to ERDA on the program direction that could yield the highest net social benefits. 


\section{CONTENTS}

SUMMARY

LIST OF FIGURES.

LIST OF TABLES .

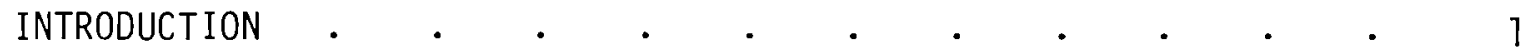

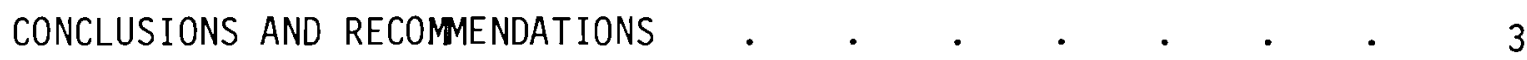

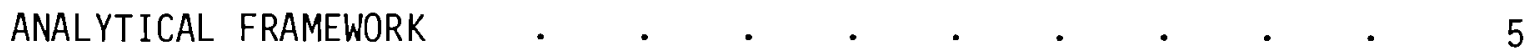

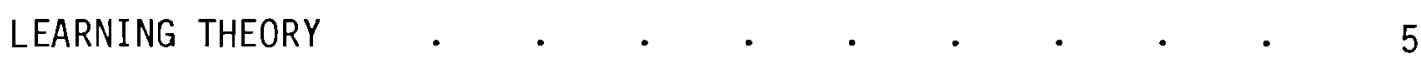

TECHNOLOGICAL DIFFUSION •

MODEL DESCRIPTION

Probabilities and the Future Wet/Dry Market . . . 11

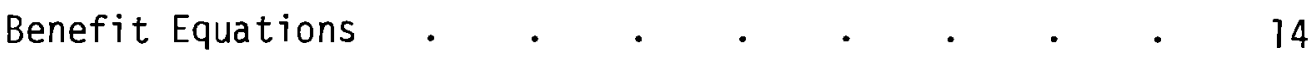

Other Assumptions .

MODEL VERIFICATION .

RESULTS •

CASE I: SOA VERSUS $\mathrm{NH}_{3}$ WITH INSTANTANEOUS LEARNING $\cdot \cdot 19$

CASE II: SOA VERSUS NH $\mathrm{NH}_{3}$ WITH LEARNING $\cdot \cdot \cdot \cdot \cdot \cdot \cdot \cdot 19$

CASE III: $\mathrm{NH}_{3}$ WITH DIFFERENT GROWTH • • • • • $~ 22$

MODEL SENSITIVITY $\cdot$ •

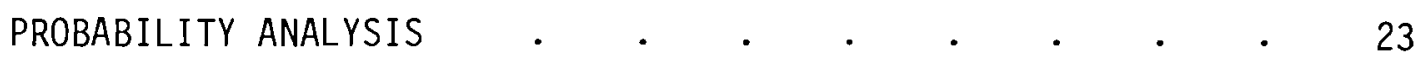

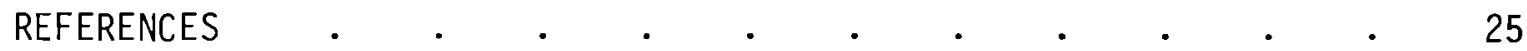

APPENDIX A - THERMAL ELECTRIC AND DRY COOLING
ADDITIONS TO THE YEAR 2000. . . . . . A-1

APPENDIX B - PROBABILITY ANALYSIS CURVES . . . . . . B B-1 
. 


\section{FIGURES}

1 Market Penetration Rate . . . . . . . . . . 7

2 Twenty Percent Wet System Learning Curves . . . . . 10

3 Fifty Percent Wet System Learning Curves . . . . . 10

4 Benefits if 20 GWe by Year 2000, 20 Percent Wet . . . 20

5 Benefits if 20 GWe by Year 2000, 50 Percent Wet . . . 21

B-1 Case I, 20 Percent Wet . . . . . . . . . . . B-1

B-2 Case II, 20 Percent Wet . . . . . . . . . . . B-2

B-3 Case III, 20 Percent Wet, $Z=0.7$. . . . . . . B-3

B-4 Case III, 20 Percent Wet, $Z=0.85$. . . . . . B-4

B-5 Case III, 20 Percent Wet, $Z=0.95$. . . . . . . B-5

B-6 Benefits if 50 GWe by Year 2000, 20 Percent Wet . . . B-6

B-7 Case I, 50 Percent Wet . . . . . . . . . . B-7

B-8 Case II, 50 Percent Wet . . . . . . . . . . B-8

B-9 Case III, 50 Percent Wet, $Z=0.7$. . . . . . . B-9

$\mathrm{B}-10$ Case III, 50 Percent Wet, $Z=0.85$. . . . . . B-10

B-11 Case III, 50 Percent Wet, $Z=0.95$. . . . . . . B-11

B-12 Benefits if 50 GWe by Year 2000, 50 Percent Wet . . . B-12

\section{TABLES}

1 Market Level Fractions and Assigned Probabilities of Attainment for Wet/Dry Cooling Technology . . . . . 12

2 Expected Values and Standard Deviations of Gross Benefits for Cases II and III . . . . . . . . . 24

A.. 1 Thermal Electric Additions, 1981-2000 . . . . . . A-1

A-2 Projected Additions to Dry-Cooled Electric Generation (Percent of New Thermal Additions) . . . . . . . A-2

A-3 Additions to Dry-Cooled Electric Generation, MWe . . . A-3 


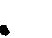

. 


\section{ESTIMATION OF BENEFITS FROM DEMONSTRATING ADVANCED WET/DRY}

COOLING TECHNOLOGY: A FRAMEWORK AND PARTIAL ANALYSIS

\section{INTRODUCTION}

This study was conducted as part of the ERDA Dry Cooling Tower Program at the Pacific Northwest Laboratory (PNL). The purpose of the analysis was to estimate the reductions in power generation costs expected to occur with a proposed demonstration of advanced wet/dry cooling technology. Experience gained by the electric power industry in building and operating new facilities can result in more efficient future production. If the information describing the experience were widely disseminated, many utilities could realize cost reductions. These cost reductions (benefits) to others would, of course, be external to the individual utility's decision whether or not to demonstrate advanced wet/dry cooling technology (and hence provide the experience). Without some means of internalizing these future cost reductions, private decisions based solely upon private benefits and costs may be inefficient from a social viewpoint. Therefore, information contained in this report is intended to assist ERDA in deciding the extent to which the pubiic should participate in demonstrating an ammonia $\left(\mathrm{NH}_{3}\right)$ cooling concept.

Wet/dry cooling technology is not generally used by the U.S. electric power industry because lower-cost options are available. For example, it is less expensive to the industry to acquire water rights and install wet cooling technology, even if doing so necessitates increased expenditures for transmitting electricity from the plant to the market or for transporting water to the plant. However, if technological improvements were to reduce either the average costs of wet/dry-cooled power generation or the uncertainty surrounding these costs, benefits could eventualiy accrue to electricity consumers through such cost reductions.

To demonstrate the technical and economic feasibility of one advanced concept, construction of a wet/dry-cooled demonstration unit equipped with 
an ammonia cooling loop has been proposed. To be erected by 1981 near Bakersfield, California, the unit would have a capacity of 6 to 10 MWe. Testing would be completed by 1983. The total cost, including testing, is estimated at $\$ 10$ million.

Cost reductions expected to occur with demonstration of the $\mathrm{NH}_{3}$ concept can be interpreted as benefits from "learning by doing", as well as benefits from reducing the uncertainty of performance, and, ultimately, costs associated with ammonia-cooled power generation systems. The extent to which consumer benefits would accrue is, of course, dependent upon the magnitude and timing of the cost reductions, as well as the fraction of thermal electric additions that would use wet/dry cooling. This study considers these cost reductions, but does not represent a comprehensive benefit-cost analysis. Hence, other significant benefits and costs, such as the value to society of the environmental impacts of wet/dry cooling versus those of other cooling technologies, are not quantified.

This report describes the analytical framework and data used in developing the model for analyzing expected cost reductions. The model and its limitations are discussed. Results of the analysis are presented by individual case and recommendations for future work are included. 


\section{CONCLUSIONS AND RECOMMENDATIONS}

It was concluded that the benefits, in the form of future cost reductions, would probably exceed the expected costs of the proposed advanced wet/dry cooling technology demonstration.

- If commercialization of ammonia $\left(\mathrm{NH}_{3}\right)$ cooling were to result without a public investment in demonstration for 50 percent wet systems, the expected gross benefits from demonstration range from $\$ 2$ million to $\$ 33$ million, depending on market penetration rates. For 20 percent wet systems, the expected gross benefits range from $\$ 8 \mathrm{million}$ to $\$ 48$ million.

- If commercialization without the demonstration were to proceed at a rate of 15 percent less than with demonstration, there is an approximately 80 percent chance that the benefits from demonstration would exceed $\$ 8$ million.

- If commercialization of $\mathrm{NH}_{3}$ cooling could only be achieved with a publicly-funded demonstration, the expected gross benefits from demonstration are estimated to be $\$ 71 \mathrm{million}$ for 50 percent wet systems and $\$ 98$ million for 20 percent wet systems.

These numbers represent best estimates. However, the reader is cautioned that the benefit estimates are extremely sensitive to small changes in the engineering-estimated learning functions, the market penetration rate of wet/dry cooling and the discount rate.

No conclusions were drawn regarding commercialization of ammonia cooling without demonstration. However, based on this analysis and a review of theoretical and empirical work on technological substitution and diffusion, it is hypothesized that ammonia cooling or some form of advanced wet/dry cooling technology will eventually be commercialized without public investment in demonstration. Hence, it is recommended that the above hypothesis be rigorously investigated. Such an investigation would necessitate studying the fundamental causes for technological diffusion, 
the willingness to pay (economic demand) for cooling water and the role of information in imperfectly competitive markets. This investigation should be supported by:

- an analysis of the rates of diffusion of new capital intensive technology in other similarly-structured markets;

- estimates of the future economic supply (price-quantity relationships) of cooling water on a regional basis; and

- estimates of the monetary value to society of the environmental impacts from different cooling alternatives.

These efforts should result in either acceptance or rejection of the hypothesis as well as better overall estimates of the future wet/dry cooling market with and without demonstration. 


\section{ANALYTICAL FRAMEWORK}

A comprehensive benefit-cost analysis of a proposed wet/dry cooling demonstration would include:

- the cost reductions and future savings that may accrue to wet/dry cooling users as a result of the knowledge acquired during the demonstration project;

- monetary quantification of the opportunity costs of the resources used in the demonstration;

- the values of the environmental impacts of dry cooling and alternative cooling technologies;

- the value of the demonstration to other RD\&D;

- estimates of the optimal size of the demonstration investment; and

- estimates of the year in which the investment would maximize net social benefits.

Although extensive theoretical and applied literature exists on all of these items, $(1-10)$ only the first falls within the scope of this analysis. If it is assumed that the sum of the net benefits on the items not addressed is non-negative, it is possible to evaluate (from an expected improvement in economic efficiency) the demonstration plant by estimating benefits in the form of future cost reductions accruing to users of wet/dry cooling as a direct result of the demonstration project.

To estimate these benfits, elements of learning theory and the theory of technological diffusion were incorporated into a stochastic model. This model estimates a distribution of benefits from learning over time and discounts these benefits back to the beginning of the demonstration project.

\section{LEARNING THEORY}

Learning by doing is an important concept when estimating the benefits from technology RD\&D, and an extensive literature exists on this subject. (11-18) The problem has been cast in proper economic perspective by Arrow, who views it as encompassing intertemporal and international shifts in production functions. (16) 
Several available empirical stucies have estimated the increase in productivity from learning as a function of capacity, output, and duration of production time. $(17,19-23)$ Much early empirical work centered on labor productivity in the airframe iridustry. In 1936, Wright ${ }^{(19)}$ demonstrated that the number of labor-hour's expended in producing an airframe is a decreasing function of the total number of airframes of the same type previously produced. In 1949, Alchiän ${ }^{(21)}$ performed a statistical analysis on airframe data to estimate several different functions to be used in estimating production costs. He found a significant negative relationship between per unit costs and quantity produced.

Only recently has learning theory within a rigorous economic analysis been empirically applied to new technology. Rausser et al. (22) investigated external benefits from a water desalting plant. The analysis incorporated Bayesian methods using both prior and posterior information. Willis performed a similar analysis on the production of methane from chicken waste. ${ }^{(23)}$ He also made use of prior and posterior information.

Methodology and findings of this previous research were freely employed in estimating the benefits from learning expected to result from demonstrating advanced wet/dry cooling technology. The benefits are estimated as distributions, thus providing information on the expected value of benefit estimates as well as the variance about the expected values. No other benefits and costs are quantified in this analysis.

\section{TECHNOLOGICAL DIFFUSION}

The theory of technological diffusion, that is, the examination of the rapidity of, and underlying reasons for, industry adoption of new technology, is also well-documented. $(18,24-30)$ Technological adoption tends to proceed along a logistics or S-shaped curve, slowly at first and then more rapidly, slowing again as it approaches its ceiling or ultimate equilibrium level. In Figure 1, T represents the diffusion period or the time required to reach ultimate equilibrium. The vertical axis usually 


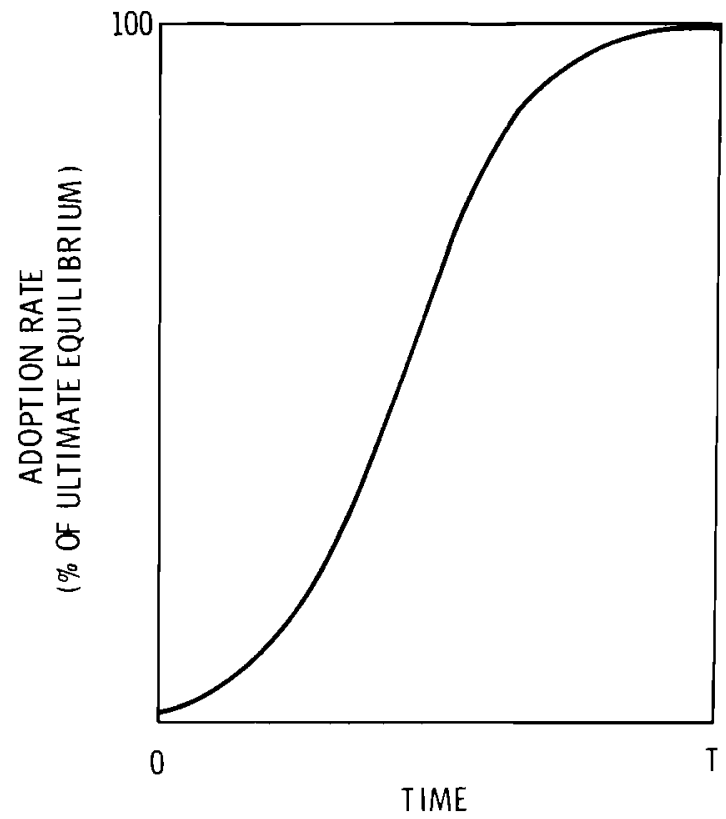

FIGURE 1. Market Penetration Rate

measures cumulative adoption as a percentage of ultimate equilibrium level. Historically, diffusion periods have ranged from 9 years for detergents to substitute for soap, to 18 years for synthetic fibers to replace natural fibers in tires, to 75 years to substitute steam ships for sailing ships.

The driving forces for technological innovation in the past have been a technological achievement, a military threat or competition in business. Increasingly, however, it appears that technological innovation will be driven by environmental concerns and fears of resource depletion.

Many reasons are postulated to explain why the diffusion processes proceed along an S-shaped curve rather than jumping immediately to an equilibrium level. Among these are: 1) imperfect flow of information from user to potential users, 2) age distribution of existing capita 1 stock, 3) anticipation of changes in quality and price of new technology, and 4) supply bottlenecks. 
In this analysis, a Gompertz curve having the form

$$
y=c s^{\beta^{t}}
$$

was used to describe the rate of technological diffusion, where

$$
\begin{aligned}
& y=\text { the percentage of equilibrium attained in year } t \\
& \alpha=\text { constant }<1 \\
& \beta=\text { constant }<1 \\
& t= \\
& \quad \text { time in years since the start of wet/dry cooling } \\
& \text { technology adoption. }
\end{aligned}
$$

\section{MODEL DESCRIPTION}

As stated earlier, the model is firmly based on learning theory literature. Much empirical evidence derived from statistical analysis supports the general learning theory hypothesis that unit costs of production decrease as the cumulative total of units produced or as the cumulative total of time spent in doing increases. The generally accepted form of the equation is

$$
A C=e^{a} C A P^{b}+A S
$$

where

$$
\begin{aligned}
A C & =\text { average cost per unit produced } \\
\mathrm{a}, \mathrm{b} & =\text { parameters to be estimated } \\
\mathrm{CAP} & =\text { surrogate for cumulative production/time } \\
\mathrm{e} & =\text { the constant } 2.718 \\
\mathrm{AS} & =\text { minimum average cost asymptote. }
\end{aligned}
$$

The preceding formulation lends itself to simple statistical estimation of the parameters after subtracting AS from both sides and taking logarithms. This yields

$$
\ln (A C-A S)=a+b \ln C A P
$$


Parameters $a$ and $b$ can then be estimated by regressing the log of (AC - AS) on the $\log$ of cumulative capacity. In this equation, $b$ represents the learning rate. It can be shown that doubling the cumulative capacity (or an appropriate surrogate) will lead to a cost decrease of $\left(1-2^{b}\right) 100$ percent. A typical and often-quoted value for $b$ is $-0.322,(32)$ indicating a 20-percent reduction in costs per unit produced for each doubling of capacity.

The absence of previous experience with advanced wet/dry cooling technology necessitated employing available engineering cost estimates. Comparisons of incremental power production costs of wet/dry cooling system options $(33-35)$ indicated that average costs of cooling decrease as the percentage of wet to dry increases for a given system.

Using these estimates, three basic assumptions were formulated for this model:

- Initially, incremental power production costs for $\mathrm{NH}_{3}$ systems would be the same as those for state-of-the-art metal finned tube (SOA) systems; those costs would reduce to the estimated advanced system costs only after equipping 1500 MWe of electric generating capacity with $\mathrm{NH}_{3}$ cooling.

- With continued learning, the $\mathrm{NH}_{3}$ system added cost could be expected to decrease asymptotically to approximately 85 percent of the cost at 1500 MWe installed capacity.

- Incremental power production costs for SOA systems would be reduced asymptotically to approximately 85 percent of current costs.

The learning curves for 20 and 50 percent wet systems are shown in Figures 2 and 3 . Curve B represents the SOA cooling system learning curve; Curve $\mathrm{D}$ represents the $\mathrm{NH}_{3}$ system learning curve. The case in which no learning occurs in SOA dry cooling systems is illustrated by Curve $A$. Curve $C$ represents the occurrence of instantaneous learning and costs do not decrease with increases in installed capacity.

Market penetration is depicted in this model with an S-shaped curve approaching a predetermined ultimate equilibrium level over time. The diffusion period (i.e., time required to reach equilibrium) is approximately 


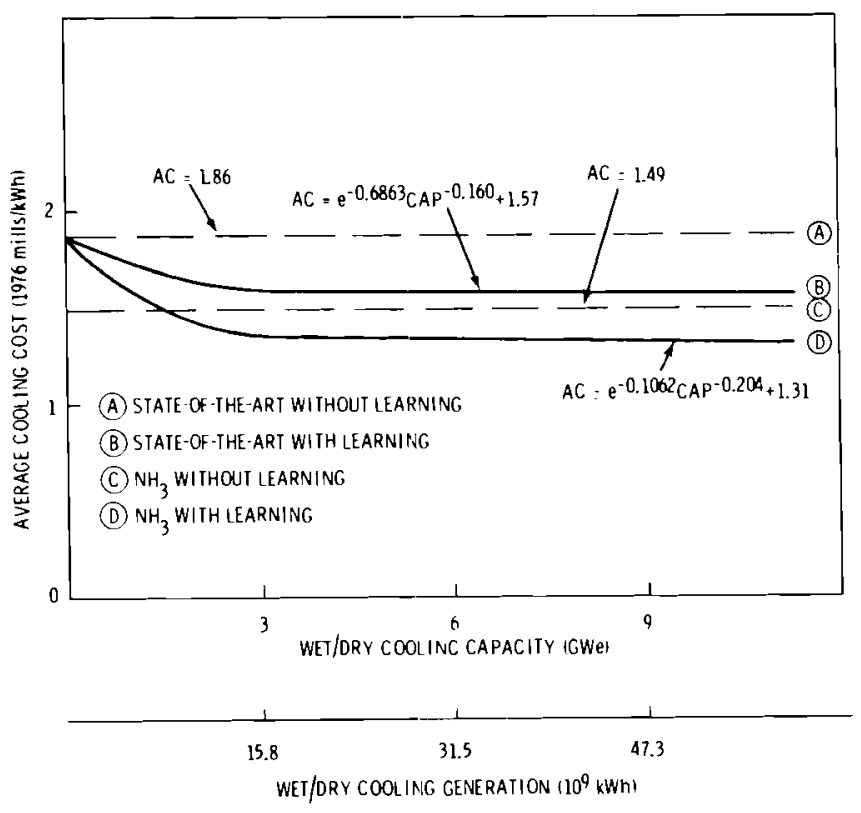

FIGURE 2. Twenty Percent Wet System Learning Curves

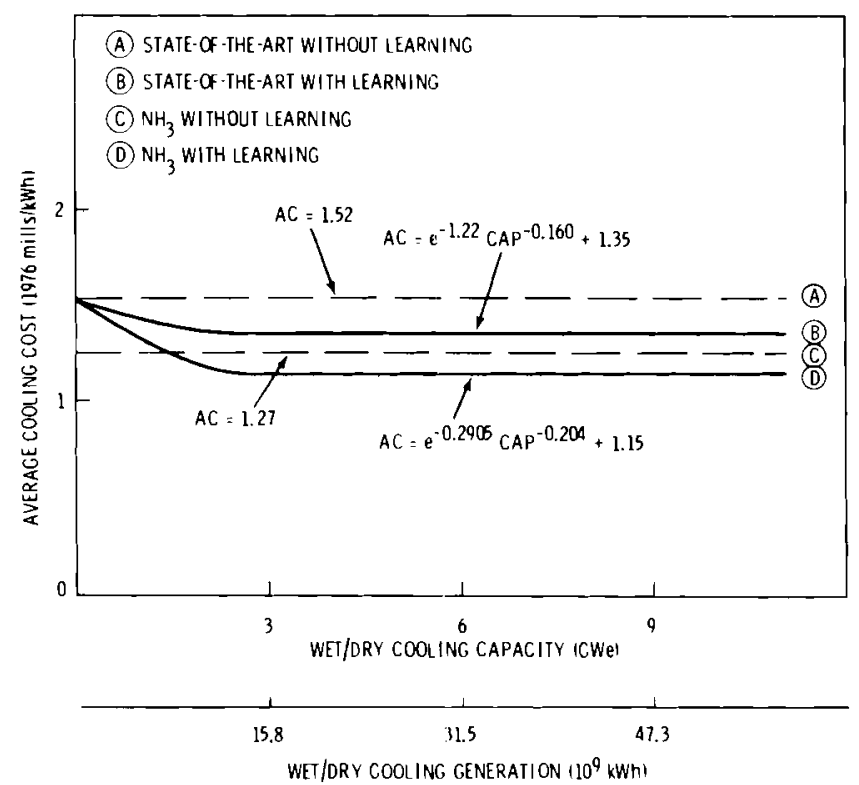

FIGURE 3. Fifty Percent Wet System Learning Curves 
40 years but by the 12 th year one-half the ultimate equilibrium has been attained. A Gompertz function was used and has the form

$$
y=\alpha^{\beta^{t}}
$$

where

$$
\begin{aligned}
& \alpha=0.01 \\
& \beta=0.85 .
\end{aligned}
$$

When $t$ is equal to 12 as stated above, $y=0.52$, or 52 percent of the ultimate equilibrium level has been attained.

Probabilities and the Future Wet/Dry Market

Considerable uncertainty exists in estimating the learning function parameters and the expected future wet/dry cooling technology market. Probability functions are recommended to explicitly account for this uncertainty. (36) Accounting for the uncertainty permits the analyst to report sensitivity of benefit estimates to changes in specific model parameters in terms of benefit probability and expected value. The learning curve parameters were estimated by using a pseudo random number generator to draw random deviates from probability density functions with means equal to the parameters as shown in Figures 2 and 3 . The parameter $b$ was chosen from a gamma density function because this form does not allow for negative learning and agrees with information derived by other researchers.

The parameter a was calculated by first selecting a random deviate $b$ from the gamma distribution, then selecting a random deviate, AA, from a normal distribution with a mean equal to the difference between the initial incremental cost of wet/dry cooling and the expected minimum cost. The parameter $a$ is then

$$
a=\ln A A+b \ln (31.536)
$$

where 31.536 is the number of $\mathrm{kWh}$ (millions) generated by a 6-MWe demonstration plant with a capacity factor of 0.6 and $A A$ is equal to (AC - AS) in Equation (3). 
The rate of wet/dry cooling technology commercialization was also treated probabilistically. Each of fifteen different ultimate market equilibrium levels was assigned a probability of attainment with the sum of the fifteen probabilities equal to one. This required choosing a probability distribution and appropriate parameters. The probability of attainment distribution was assumed to be skewed similar to a gamma distribution (see Table 1). Next, the mode and range were chosen. This step required information on the expected future demand for wet/dry cooling or, as a minimum, a subjective evaluation of the future wet/dry cooling market. The approach used was to relate the future market of wet/dry cooling to national market forecasts of thermal electric additions to the year 2000 .

TABLE 1. Market Level Fractions and Assigned Probabilities of Attainment for Wet/Dry Cooling Technology

\begin{tabular}{|c|c|c|c|}
\hline \multicolumn{2}{|c|}{$\begin{array}{l}\text { Ultimate Equilibrium } \\
\text { (Fraction of New } \\
\text { Cooling Capacity) }\end{array}$} & $\begin{array}{l}\text { Fraction of Thermal } \\
\text { Electric Additions } \\
1985-2000\end{array}$ & \multirow{2}{*}{$\begin{array}{l}\text { Probability } \\
\quad \text { of } \\
\text { Attainment } \\
\end{array}$} \\
\hline$t=\infty$ & $t=15$ & & \\
\hline .02 & .01 & .007 & .0025 \\
\hline .04 & .03 & .014 & .0100 \\
\hline .06 & .04 & .020 & .0400 \\
\hline .08 & .06 & .028 & .1000 \\
\hline .10 & .07 & .034 & .1500 \\
\hline .12 & .09 & .041 & .3000 \\
\hline .14 & .10 & .048 & .1500 \\
\hline .16 & .11 & .054 & .1000 \\
\hline .18 & .13 & .062 & .0400 \\
\hline .20 & .14 & .069 & .0300 \\
\hline .22 & .16 & .075 & .0250 \\
\hline .24 & .17 & .083 & .0200 \\
\hline .26 & .19 & .089 & .0150 \\
\hline .28 & .20 & .096 & .0125 \\
\hline .30 & .21 & .103 & .0050 \\
\hline
\end{tabular}


Two recent studies have used this approach. Proceeding from national forecasts of thermal electric additions, both studies regionalized and compared water consumption requirements of these forecasts to projected unallocated regional water supplies to the year 2000 .

The first study, prepared by the General Electric Company (GE), projected 6 to 23 GWe of wet/dry cooling for nuclear power plants by the year 2000. (35) No estimate was given for fossil-fired plants. However, Hendrickson used the GE data to derive an estimate of 5 to 19 GWe for fossil-fired plants. (36) Combining the two estimates yields a total projected addition of 11 to 42 GWe by the year 2000 .

The second study, (37) by Petersen and Sonnichsen of the Hanford Engineering Development Laboratory (HEDL), used power projections normalized to forecasts published in Nuclear Power Growth, 1973-2000, WASH-1139. These projections were then dispersed into localized patterns and assigned to Water Resource Regions and Subregions. The authors assumed that a maximum of 10 percent of the once-in-ten-year monthly low flow would be available for thermal power plant consumptive use. Using this and information on institutional constraints, the authors made a judgmental forecast of expected future occurrences of dry and wet/dry cooling in each region. They estimated between 24 and 44 MWe of wet/dry cooling nationally by the year 2000 .

Both studies assumed no water transfers from other uses to power plant cooling. Hendrickson found that, on the average, water is worth at least five times as much to a utility as to a farmer. (36) He also found that institutional constraints to water rights transfers currently exist in two western states, California and Montana. Over half the projected future use of wet/dry cooling is in California. However, if water rights transfers continue to be allowed in other states, the future additions of wet/dry cooling will probably be at the lower end of the above estimates. Hendrickson, in fact, suggests 20 GWe by the year 2000 as a reasonable estimate. 
The national forecast of thermal electric additions used in this analysis is the low growth forecast of Table A-1. This forecast is consistent with current econometric estimates and with intentions to add capacity noted in recent issues of Electric World. By summing the thermal additions over all water Resource Regions for the HEDL low growth case a national forecast is available for comparison. The low growth case of the GE report may be compared directly with the additions to 2000 used in this report. Both the HEDL and GE forecasts of thermal electric additions on which the forecasts for wet/dry cooling were based are twice those used in this analysis. Thus, Hendrickson's estimate of 20 GWe of wet/dry cooling by the year 2000 was chosen as the most likely to occur. This was assigned the highest probability of attainment, 0.30 , at an ultimate equilibrium of 0.12 . Thus, it is estimated that, at time equals infinity, there is a 30 percent chance that wet/dry cooling will capture 12 percent of the cooling market of the additions to thermal electric capacity. Further, this represents 20 GWe. It is also estimated that wet/dry cooling has a 30 percent chance of capturing 9 percent of the new market in the year $2000(t=15)$. Between the years 1985 and 2000 it is estimated that wet/dry cooling has a 30 percent chance of capturing 4.1 percent of the additions to thermal electric capacity. The yearly fraction that would accrue to wet/dry cooling for each equilibrium level is given in Appendix A.

\section{Benefit Equations}

Given the learning curves shown in Figures 2 and 3 , the market penetration rates as calculated by the Gompertz function, projections of additions to thermal electric generating capacity, estimated probabilities of attaining selected ultimate market equilibrium levels, average life of new thermal generating plants and the discount rate, equations can now be written for estimating benefits from learning that accrue to a demonstration of a plant equipped with an $\mathrm{NH}_{3}$ cooling loop. 
Benefits were estimated for three separate cases characterized by differing assumptions on ultimate equilibrium levels for $\mathrm{SOA}$ and $\mathrm{NH}_{3}$ cooling.

\section{Case 1: SOA Versus $\mathrm{NH}_{3}$ with Instantaneous Learning}

Case 1 is represented by Curves $A$ and $C$ in Figures 2 and 3 . This is the most naive of the cases examined. Benefits from the demonstration can be defined as the cost differential (ammonia versus state-of-the-art) for each plant over its 40-year life discounted back to the start of the demonstration project (1979). Throughout all the analyses, benefits from only those plants projected to adopt wet/dry cooling between 1985 and 2000 were included. The benefits equation then is

$$
\text { BEN }=\sum_{i=1985}^{2000} \sum_{j=i}^{j+39}\left(\frac{1}{(1+R)}\right)^{(j-1979)}\left(C_{1}-C_{2}\right) \text { NEWCAP }_{i}
$$

where

$R=$ discount rate in real terms (i.e., inflation excluded)

$c_{1}=1.86$ for 20 percent wet; 1.52 for 50 percent wet

$c_{2}=1.49$ for 20 percent wet; 1.27 for 50 percent wet $\operatorname{NEWCAP}_{j}=$ new wet/dry-cooled generation $\left(10^{6} \mathrm{kWh}\right)$ in year $i$ and is calculated in the code as NEWCAP $=\alpha^{\beta^{\mathrm{t}}}\left(\right.$ TOTEL $\left._{i}\right)$ (EQUIL)

where

$$
\begin{aligned}
\text { TOTEL }_{\mathbf{i}}= & \text { projected additions to all thermal generation in } \\
& \text { year } \mathbf{i}\left(10^{6} \mathrm{kWh}\right) \\
\text { EQUIL }= & u 1 \text { timate equilibrium level for wet/dry cooling as } \\
& \text { a percentage of total new thermal additions } \\
\alpha, \beta= & \text { parameters of the Gompertz function } \\
t= & (i-1984) .
\end{aligned}
$$




\section{Case II: SOA Versus $\mathrm{NH}_{3}$ with Learning}

Case II assumes learning as depicted by Curves $B$ and $D$ in Figures 2 and 3 . The benefits equation is

$$
\begin{array}{r}
\mathrm{BEN}=\sum_{i=1985}^{2000} \sum_{j=1}^{i+39}\left(\frac{1}{(1+R)}\right)^{(j-1979)} \operatorname{NEWCAP}_{i}\left[\left(e^{A 2} \operatorname{DCCAP}_{i}^{B 2}+A S 2\right)\right. \\
\left.-\left(e^{A} \operatorname{DCCAP}_{i}^{B}+A S\right)\right]
\end{array}
$$

where $R$ and NEWCAP $i$ are as described in Case 1

and

$$
\operatorname{DCCAP}_{i}=\sum_{j=1985}^{i} \text { NEWCAP }_{i}
$$

and $A, A 2, B$ and $B 2$ are parameters, and AS2 and AS are asymptotes, from learning curves $B$ and $D$ in Figures 2 and 3.

\section{Case III: $\mathrm{NH}_{3}$ with Different Growth}

Case III assumes learning as depicted by Curve $C$ in Figure 2, but allows for the adoption of ammonia cooling at a reduced penetration rate even if there is no demonstration. Because of the different market penetration rates, the benefits from learning for each penetration rate relative to a no-learning case were measured separately. The benefit equation for this case is BEN = BEN1 - BEN2 where BEN1, the benefits from learning given a demonstration plant, is defined as

$$
\text { BEN1 }=\sum_{i=1985}^{2000} \sum_{j=i}^{i+39}\left(\frac{1}{(1+R)}\right)^{(j-1979)} \operatorname{NEWCAP}_{i}\left[C_{1}-\left(e^{A} \operatorname{DCCAP}_{i}^{B}+A S\right)\right]
$$

and BEN2, the benefits from learriing assuming no demonstration, is defined as

$$
\text { BEN2 }=\sum_{i=1985}^{2000} \sum_{j=i}^{i+39}\left(\frac{1}{(1+R)}\right)^{(j-1979)} \operatorname{XNEWCAP}_{i}\left[C_{1}-\left(e^{A} \operatorname{XDCCAP}_{i}^{B}+A S\right)\right]
$$


where

R, NEWCAP ${ }_{i}$ and DCCAP $_{i}$ are as defined in Cases I and II and

$$
\begin{aligned}
\text { XNEWCAP }^{=} & (\operatorname{NEWCAP})(Z) \\
Z= & 0.7,0.85 \text { or } 0.95 \\
\text { XDCCAP }_{i}= & \sum_{j=1985}^{i} \text { XNEWCAP }_{i} \\
\text { AS } & 1.31 \text { for } 20 \text { percent wet; } 1.15 \text { for } 50 \text { percent wet from } \\
& \text { Figures } 2 \text { and } 3 \\
A_{3} B= & \text { parameters from 1earning curve } D \text { in Figures } 2 \text { and } 3 \\
C_{1}= & 1.86 \text { for } 20 \text { percent wet; } 1.52 \text { for } 50 \text { percent wet. }
\end{aligned}
$$

\section{Other Assumptions}

In most analyses, the results are extremely sensitive to the assumptions used. For this reason, the cther assumptions used in this analysis will now be explicitly defined.

The discount rate used in calculating the "best" estimates was 7 percent in real terms. This means that the effects of inflation are removed and the benefits and costs are in constant dollars.

The computer model adds wet/dry cooling capacity in units of 200 MWe. If actual capacity were added in units greater than 200 MWe, the benefits will have been slightly overestimated in this analysis. Table A-3 shows how much capacity is added in each year under assumptions of different growth rates.

\section{MODEL VERIFICATION}

Verification of the model was an important consideration. The first step was to hand-calculate the most naive case (Case I), instantaneous learning. The results were then compared with output from the computer algorithm for Case I. 
Verification of Cases II and III was accomplished by performing several simulations while varying different parameters to see if the results "made sense" in relative terms. For example, an increase in the discount rate must result in a reduction of benefits, everything else being equal. When it appeared that the computer output was correct, a run was made for both Case II and III, printing out variables each time a calculation was made. The results were duplicated by hand calculations for a four-year time horizon in each case. This completed the model verification. 


\section{RESULTS}

The results presented in Figures 4 and 5 show gross benefits as a function of the discount rate from 20 GWe by the year 2000 . These results represent the means of the benefit distributions at each discount rate.

CASE I: SOA VERSUS $\mathrm{NH}_{3}$ WITH INSTANTANEOUS LEARNING

Case I, Figure 4 and 5 , is underlain with four assumptions:

- Without demonstrating ammonia cooling, the average cost differential using state-of-the-art technology over zero-cost cooling will forever be constant at $1.86 \mathrm{mills} / \mathrm{kWh}$ for 20 percent wet and $1.52 \mathrm{mi} 1 \mathrm{~s} / \mathrm{kWh}$ for 50 percent wet.

- With the demonstration, the average cost differential instantaneously drops to $1.49 \mathrm{mills} / \mathrm{kWh}$ for 20 percent wet and $1.27 \mathrm{mi} 1 \mathrm{~s} / \mathrm{kWh}$ for 50 percent wet, and remains forever constant.

- The demonstration has no effect on the growth rate of dry cooling.

- Ammonia cooling will never occur without the demonstration.

The probability analysis indicates that the best estimate of the gross benefits from this scenario is $\$ 155$ million for 20 percent wet and $\$ 120$ million for 50 percent wet.

\section{CASE II: SOA VERSUS $\mathrm{NH}_{3}$ WITH LEARNING}

In this case, the assumption of instantaneous learning is relaxed. Costs using SOA are assumed to decrease asymptotically as capacity is increased. The probability analysis suggests that the best estimate of the gross benefits from this scenario is $\$ 98$ million for 20 percent wet and $\$ 71$ million for 50 percent wet. These represent minimum values of expected benefits for the $\mathrm{SOA}$ versus $\mathrm{NH}_{3}$ scenario because, if the rate of commercialization increased due to demonstration, the benefits would increase. 


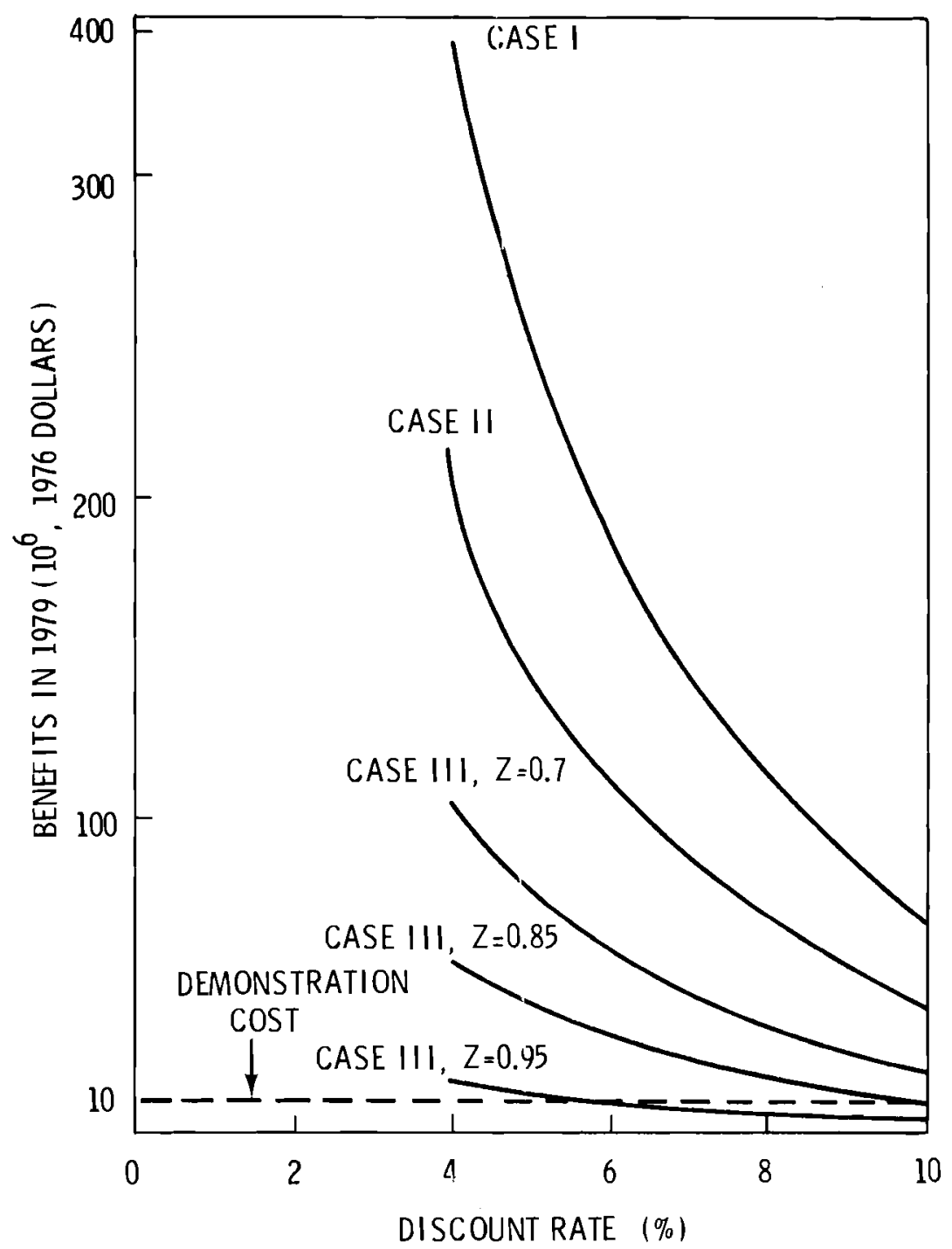

FIGURE 4. Benefits if 20 GWe by Year 2000, 20 Percent wet 


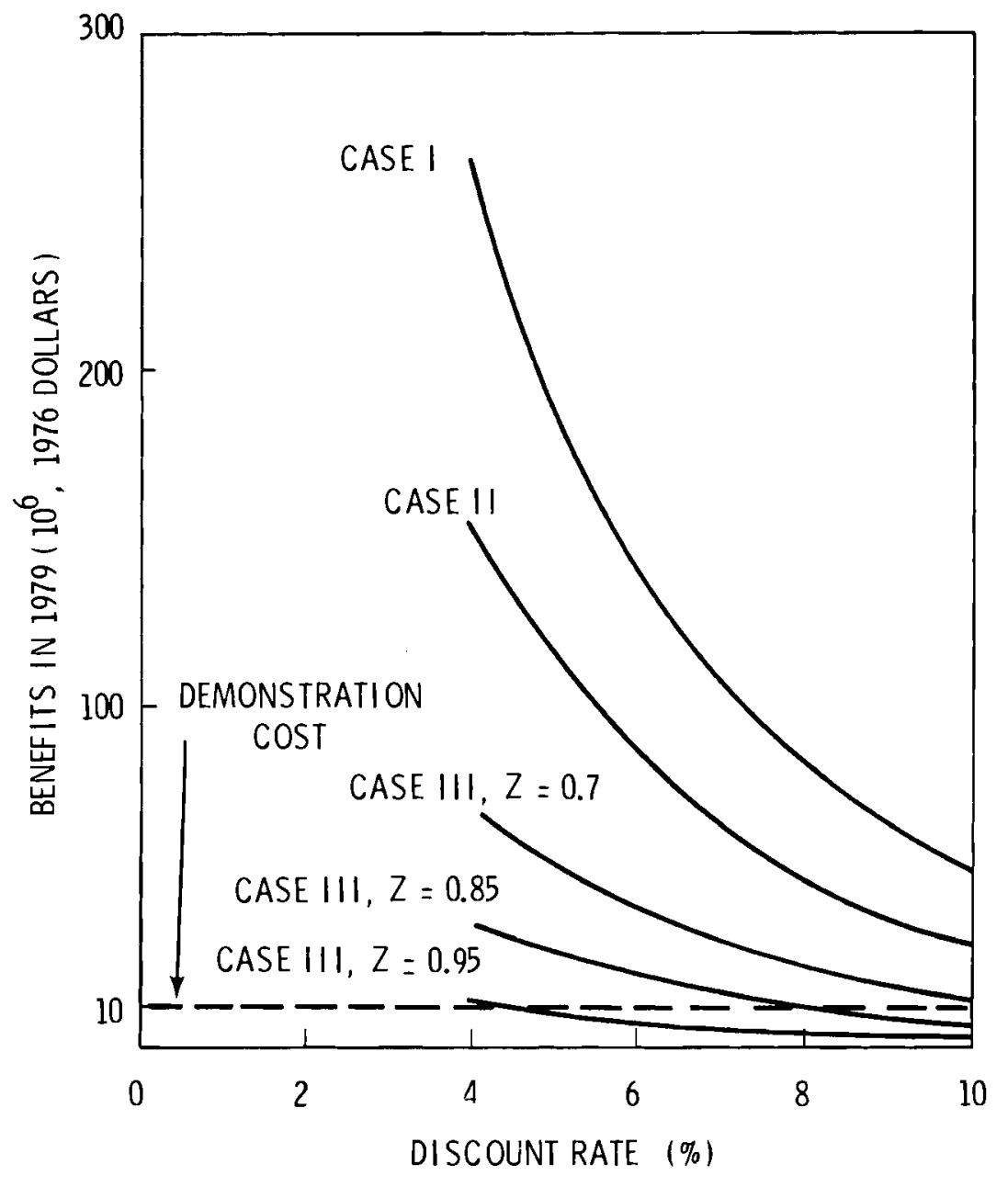

FIGURE 5. Benefits if 20 GWe by Year 2000, 50 Percent Wet 


\section{CASE III: $\mathrm{NH}_{3}$ WITH DIFFERENT GROWTH}

Two crucial assumptions of the above scenarios were that 1) ammonia cooling will never be commercialized without the demonstration and 2) the demonstration would have no effect on the market penetration rate of wet/ dry cooling. The second assumption is believed to be naive: considerable theoretical rationale and empirical evidence in other similarly-structured markets warrant relaxation of this assumption.

The first assumption is not so easily handled. Although evidence in general supports relaxation of this assumption, it is not as overwhelming as in the case of the second assumption.

For this reason, several computer runs were made to investigate how changes in the market penetration rate of wet/dry cooling due to a demonstration of advanced technology would affect the gross benefits. The assumptions for these scenarios are:

- Ammonia cooling will be commercialized regardless of whether a public investment in demonstration occurs.

- Demonstration of ammonia cooling will cause an increase in the market penetration rate of ammonia cooling.

Four scenarios were investigated where the market penetration rate without demonstration was assumed to be $70,85,95$ and 100 percent of the penetration rate with demonstration. It was found that the benefits are extremely sensitive to changes in the market penetration rate. For example, assuming identical market penetration rates for ammonia cooling with and without the demonstration (the only difference in cumulative capacity being the demonstration plant), the gross benefits are estimated to be close to zero for both 20 percent and 50 percent wet. (This curve is not shown.) However, if the penetration rate without the demonstration were 95 percent of the growth rate after demonstration, the gross benefits estimated from the probability analysis are $\$ 8$ million for 20 percent wet and $\$ 3$ million for 50 percent wet. The gross benefits would increase to $\$ 48$ million and $\$ 33$ million, respectively, if the before-demonstration growth rates were 70 percent of the growth rate after demonstration. 


\section{MODEL SENSITIVITY}

It was found that the expected benefits are sensitive not only to the relative growth rates for wet/dry cooling with and without demonstration, but also to the absolute growth rates with and without demonstration. For example, it was found that, over a wide range of capacity, a doubling of installed wet/dry cooling capacity between 1985 and 2000 would approximately double the expected benefits for each scenario investigated.

The analysis also indicated that the benefit estimates are extremely sensitive to the real rate of interest used. Rates of 4,7 and 10 percent were used for each scenario. The estimated benefits at an interest rate of 4 percent were about twice those reported at an interest rate of 7 percent. Use of a 10-percent interest rate resulted in about half the benefits generated with a 7-percent interest rate.

\section{PROBABILITY ANALYSIS}

Cases I, II and III were run on the computer 50 times each for the fifteen different ultimate market equilibrium levels. The 50 values for each equilibrium level were then multiplied by the corresponding probability of attainment. The sum of these products yielded a distribution of benefits.

This analys is indicated the degree of uncertainty surrounding the estimated benefits when explicitly treating the learning function parameters and the maximum market penetration rates as having a considerable degree of uncertainty. The results of this analysis provide the "best" estimates, statistically speaking, for the most realistic scenarios and are shown in Table 2.

There are at least two very important results in Table 2. First, if $\mathrm{NH}_{3}$ cooling were to occur without a public investment in demonstration but penetrate the market at a rate of 15 percent less than had a demonstration occurred, there is an approximately 80 percent chance that gross benefits ( $\$ 8$ to $\$ 13$ million) from a demonstration would exceed the demonstration 
TABLE 2. Expected Values and Standard Deviations of Gross Benefits for Cases II and II I

Case III

\begin{tabular}{|c|c|c|}
\hline $\begin{array}{l}\text { Expected } \\
\text { Value } \\
\$ 10^{6} \\
\end{array}$ & $\begin{array}{c}\text { Standard } \\
\text { Deviation } \\
\quad \$ 10^{6} \\
\end{array}$ & $\begin{array}{c}80 \% \text { Chance That } \\
\text { Gross Benefits } \\
>\$ 10^{6} \\
\end{array}$ \\
\hline $\begin{array}{l}50 \% \\
\text { Wet }\end{array}$ & $\begin{array}{l}50 \\
\text { We }\end{array}$ & $\begin{array}{l}20 \% \\
\text { Wet }\end{array}$ \\
\hline
\end{tabular}

$\mathrm{NH}_{3} \mathrm{Vs}$. $\mathrm{NH}_{3}$

W/D growth w/o demo

$=0.95 \times$ growth with demo

8

3

4

2

$4 \quad 1$

$\mathrm{NH}_{3}$ vs. $\mathrm{NH}_{3}$

W/D growth $w / 0$ demo

$=0.85 \times$ growth with demo

24

16

11

$8 \quad 13$

8

$\mathrm{NH}_{3}$ vs. $\mathrm{NH}_{3}$

W/D growth $w / 0$ demo

$=0.7 \times$ growth with demo

48

33

23

16

25

17

Case II

$\mathrm{NH}_{3}$ vs. SOA

learning as a function

of capacity

98

71

71

48

27

23

cost. Second, if commercialization of $\mathrm{NH}_{3}$ cooling would occur only with a publicly-funded demonstration, there is an 80 percent chance that gross benefits from demonstration would exceed $\$ 23$ million. These numbers again point out the sensitivity of the estimates to

- the assumptions inherent in Cases II and III; and

- the market penetration rates with and without the demonstration.

Additional curves showing results of the analysis are presented in Appendix B. 


\section{REFERENCES}

1. P. Bohm, Social Efficiency: A Concise Introduction to Welfare Economics. MacMillan, New York, NY, 1974.

2. J. E. Tilton, U.S. Energy R\&D Policy: The Role of Economics. Resources for the Future, Inc., Washington, DC, pp. 28-41, 1974.

3. A. Phillips, ed., Promoting Competition in Regulated Markets. The Brookings Institution, Washington, DC, 1975.

4. H. M. Treking, ed., Essays on Public Utility Pricing and Regulation. Graduate School of Business Administration, Michigan State University, East Lansing, MI, 1971.

5. C. J. Cicchetti and J. L. Jurewitz, eds., Studies in Electric Utility Regulation. Ballinger Publishing Company, Cambridge, MA, 1975.

6. K. Goren-Mäler, Environmental Economics: A Theoretical Inquiry. The Johns Hopkins University Press, Baltimore, MD, 1974.

7. W. J. Baumol and W. E. Oates, The Theory of Environmental Policy. Prentice-Ha11, Inc., Englewood Cliffs, NJ, 1975.

8. C. W. Howe, Benefit-Cost Analysis for Water System Planning. Water Resources Monograph 2, American Geophysical Union, Washington, DC, 1971, Publication Press, Inc., Baltimore, MD.

9. 0. C. Herfindahl and A. V. Kneese, Economic Theory of Natural Resources. Charles E. Merri11 Publishing Company, Columbus, OH, 1974.

10. R. Dorfman, ed., Measuring Benefits of Government Investments. The Brrokings Institution, Washington, DC, 1965.

11. E. R. Hilgard, Theories of Learning. 2nd Edition, Appleton-CenturyCrofts, New York, NY, 1956.

12. L. Johansen, "Substitution vs. Fixed Production Coefficients in the Theory of Economic Growth: A Synthesis." Econometrica. 27:157-176, 1959.

13. W. Y. 0i, "The Neoclassical Foundations of Progress Functions." Econ. J. September 1967.

14. V. L. Smith, Investment and Production: A Study in the Theory of the Capital Using Enterprise. Harvard University Press, Cambridge, MA, 1966. 


\section{REFERENCES (Continued)}

15. R. M. Solow, "Some Recent Developments in the Theory of Production," The Theory and Analysis of Production. M. Brown, ed., Studies in Income and Wealth, 31 (NBER), 1967.

16. K. J. Arrow, "The Economic Implications of Learning by Doing." Rev. Econ. Stud. 29(3):155-173, 1962.

17. W. Fellner, "Specific Interpretations of Learning by Doing." Journal of Economic Theory. 1:119-140, 1969.

18. D. Sahal, "A Reformulation of the Technological Progress Function." Technological Forecasting and Social Change. 8:75-90, 1975.

19. T. P. Wright, "Factors Afferting the Cost of Airplanes." Journal of the Aeronautical Sciences. 3:122-128, 1936.

20. W. Z. Hirsch, "Manufacturing Progress Functions." Rev. Econ. Statist. 34: 143-155, 1952.

21. A. Alchian, "Reliability of Progress Curves in Airframe Production." Econometrica. 31(4):679-693, 1963.

22. G. C. Rausser, C. Willis and P. Frick, "Learning, External Benefits, and Subsidies in Water Desalination." Water Resources Research. $\underline{8}(6): 1385-1400,1972$.

23. C. E. Willis, "Learning, External Benefits and Methane Generation from Agricultural Wastes." Presented to the American Agricultural Economics Association, Columbus, OH, 1975.

24. H. Lakhani, "Diffusion of Environment-Saving Technological Change: A Petroleum Refining Case Study." Technological Forecasting and Social Change. $7(1): 1975$.

25. M. Bundgaard-Nielsen and P. Fiehn, "The Diffusion of New Technology in the U.S. Petroleum Refining Industry." Technological Forecasting and Social Change. 6(1):1974.

26. M. D. Stern, R. U. Ayres and A. Shapanka, "A Model for Forecasting the Substitution of One Technology for Another." Technological Forecasting and Social Change. 7(1):1975.

27. R. U. Ayres and A. Shapanka, "Explicit Technological Substitution Forecasts in Long-Range Input-Output Models," Technological Substitution. H. A. Linstone and D. Sahal, eds., American El sevier Publishing Company, Inc., New York, NY, pp. 143-168, 1976. 


\section{REFERENCES (Continued)}

28. A. W. Blackman, Jr., "The Market Dynamics of Technological Substitution." Technological Forecasting and Social Change. 6(1):1974.

29. A. W. Blackman, Jr., "The Rate of Innovation in the Commercial Aircraft Jet Engine Market." Technological Forecasting and Social Change. 2(3-4):1971.

30. M. N. Sharif and C. Kabir, "A Generalized Model for Forecasting Technological Substitution." Technological Forecasting and Social Change. $8(4): 1976$.

31. H. A. Linstone and D. Sahal, eds., Technological Substitution: Forecasting Techniques and Applications. American Elsevier Publishing Company, Inc., New York, NY, 1976.

32. H. Asher, Cost Quantity Relationships in the Airframe Industry. R-291, The Rand Corporation, Santa Monica, CA, pp. 1-115, 1956.

33. F. R. Zaloudek et al., A Study of the Comparative Costs of Five Wet/Dry Cool ing Tower Concepts. BNWL-2122, Battelle, Pacific Northwest Laboratories, Richland, WA 99352, September 1976.

34. Engineering and Economic Evaluation of Wet/Dry Cool ing Towers for Water Conservation. UE\&C-ERDA-761130, United Engineers and Constructors, Inc., November 1976.

35. General Electric Company, Future Needs for Dry or Peak Shaved Dry/Wet Cooling and Significance to Nuclear Power Plants. NP-150, Electric Power Research Institute, Palo Alto, CA 94304, February 1976.

36. P. L. Hendrickson, An Overview of Economic, Legal, and Water Availability Factors Affecting the Demand for Dry and Wet/Dry Cooling for Thermal Power Plants. BNWL-2268, Battelle, Pacific Northwest Laboratories, Richland, WA 99352, June 1977.

37. D. E. Peterson and J. C. Sonnichsen, Assessment of Cooling Water Supply in the United States. HEDL-TME 76-82, Westinghouse-Hanford Company, Richland, WA, September 1976.

38. A. N. Halter and G. W. Dean, Decisions Under Uncertainty. Southwestern Publishing Co., Cincinnati, OH, 1971. 


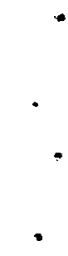


APPENDIX A

THERMAL ELECTRIC AND DRY COOLING ADDITIONS TO THE YEAR 2000 
. 
TABLE A-1. Thermal Electric Additions, 1981-2000 $(1,2)$

Low Growth Year Additions $\begin{gathered}\text { Cumulative } \\ \text { GWe }\end{gathered} 10^{6} \mathrm{kWh}^{(\mathrm{a})}$

14

1981

14

29

45

$1987 \quad 18$

$1988 \quad 18$

$1989 \quad 18$

$1990 \quad 18$

$1991 \quad 26$

$1992 \quad 26$

$1993 \quad 26$

$1994 \quad 26$

$1995 \quad 26$

199636

$1997 \quad 36$

$1998 \quad 36$

199936

2000

98

116

134

152

170

196

222

248

274

300

336

372

408

442

480
73,584

78,840

84,096

89,352

94,608

94,608

94,608
High Growth

GWe Cumulative

Additions

14

15

16

17

20

30

30

30

30

30

34

34

34

34

34

52

52

52

52

52

14

29

45

62

82

112

142

172

202

232

266

300

334

368

402

454

506

558

610

662

GWe $10^{6} \mathrm{kWh}^{(\mathrm{a})}$

73,584

78,840

84,096

89,352

105,120

157,680

157,680

157,680

157,680

157,680

178,704

178,704

178,704

178,704

178,704

273,312

273,312

273,312

189,216

273,312

189,216

273,312

(a) Assumes capacity factor $=0.6$. 
TABLE A-2. Projected Additions to Dry-Cooled Electric

Generation (Percent of New Thermal Additions)

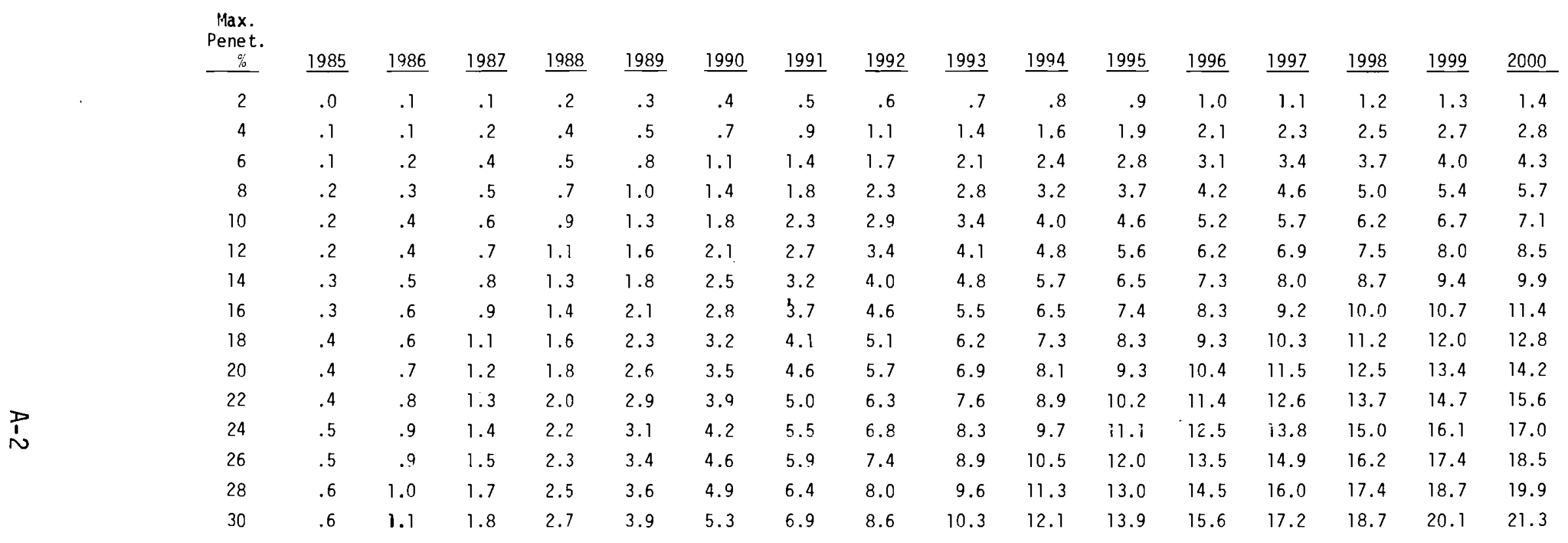




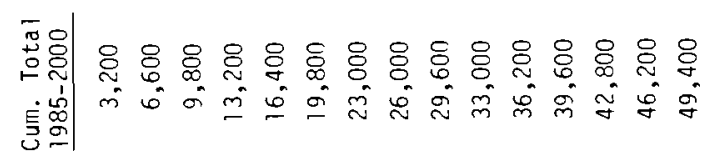

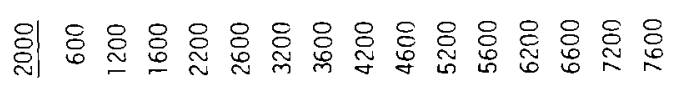

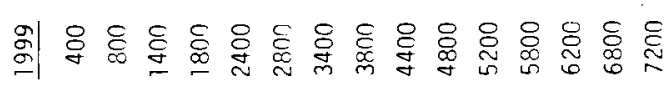

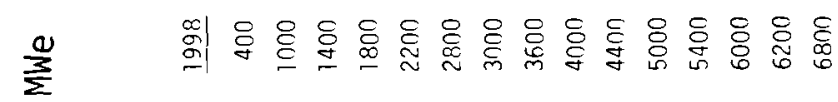

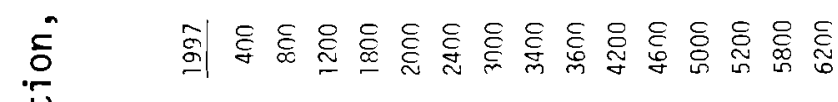

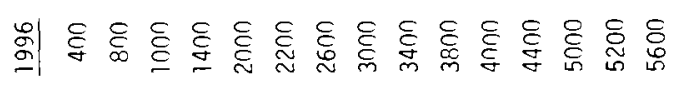

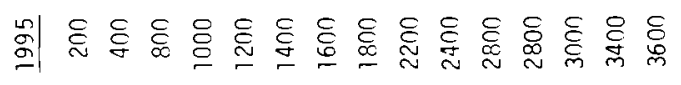

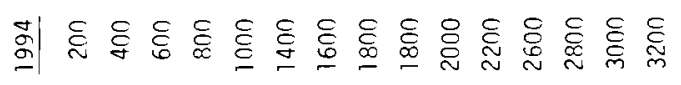

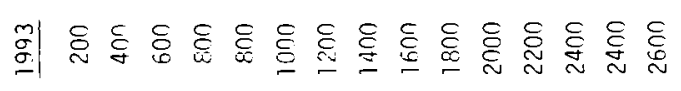

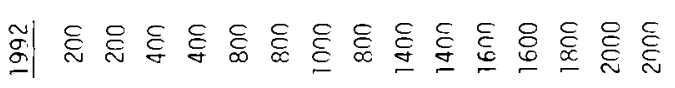

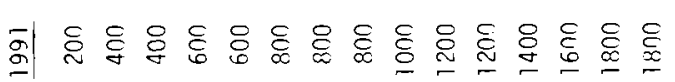

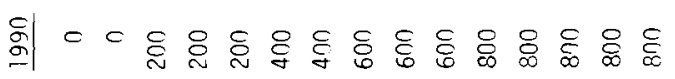

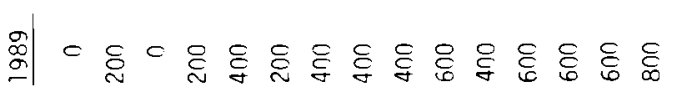

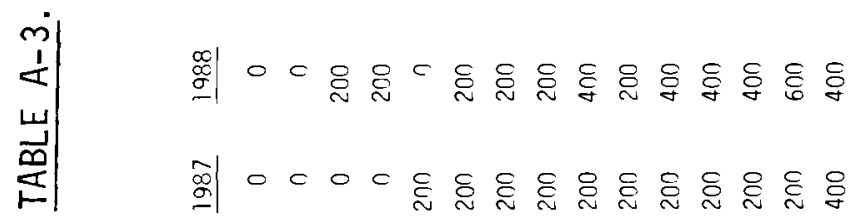

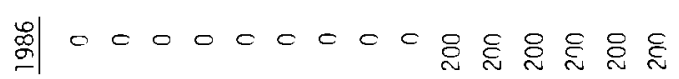

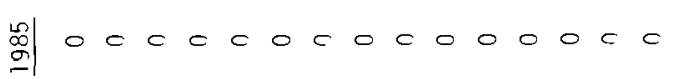

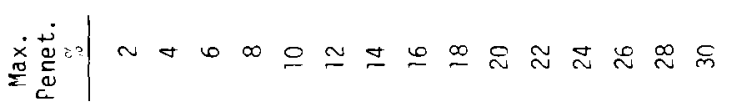




\section{APPENDIX A REFERENCES}

1. Regional Analysis of the U.S. E:Tectric Power Industry: Volume 1. Summary and Results. BNWL-B-4i5, Battelle, Pacific Northwest Laboratories, Rich1and, WA 993.52, July 1975.

2. Electric World, p. 55, September 15, 1976. 
APPENDIX B

PROBABILITY ANALYSIS CURVES 



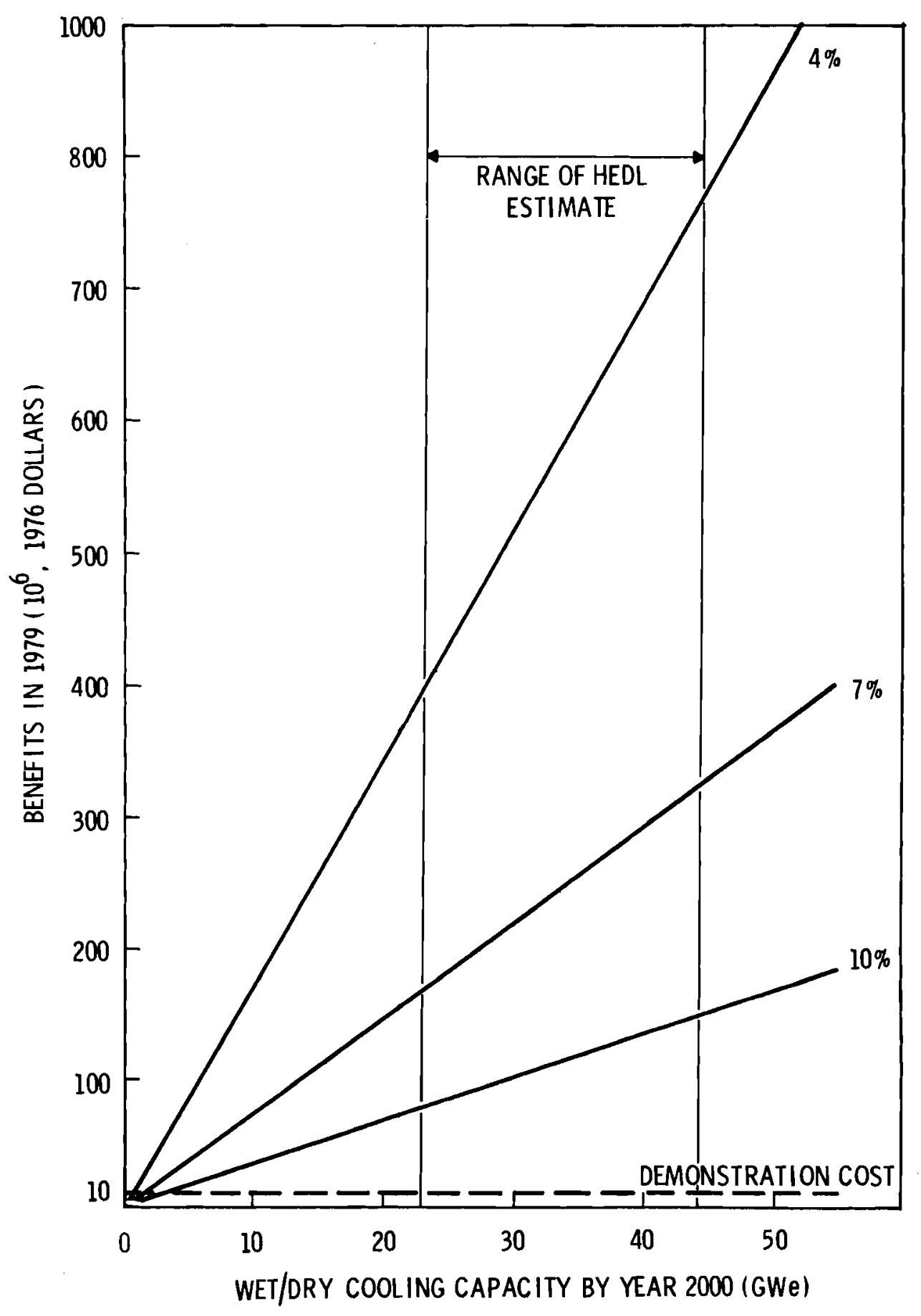

FIGURE B-1. Case I, 20 Percent Wet 


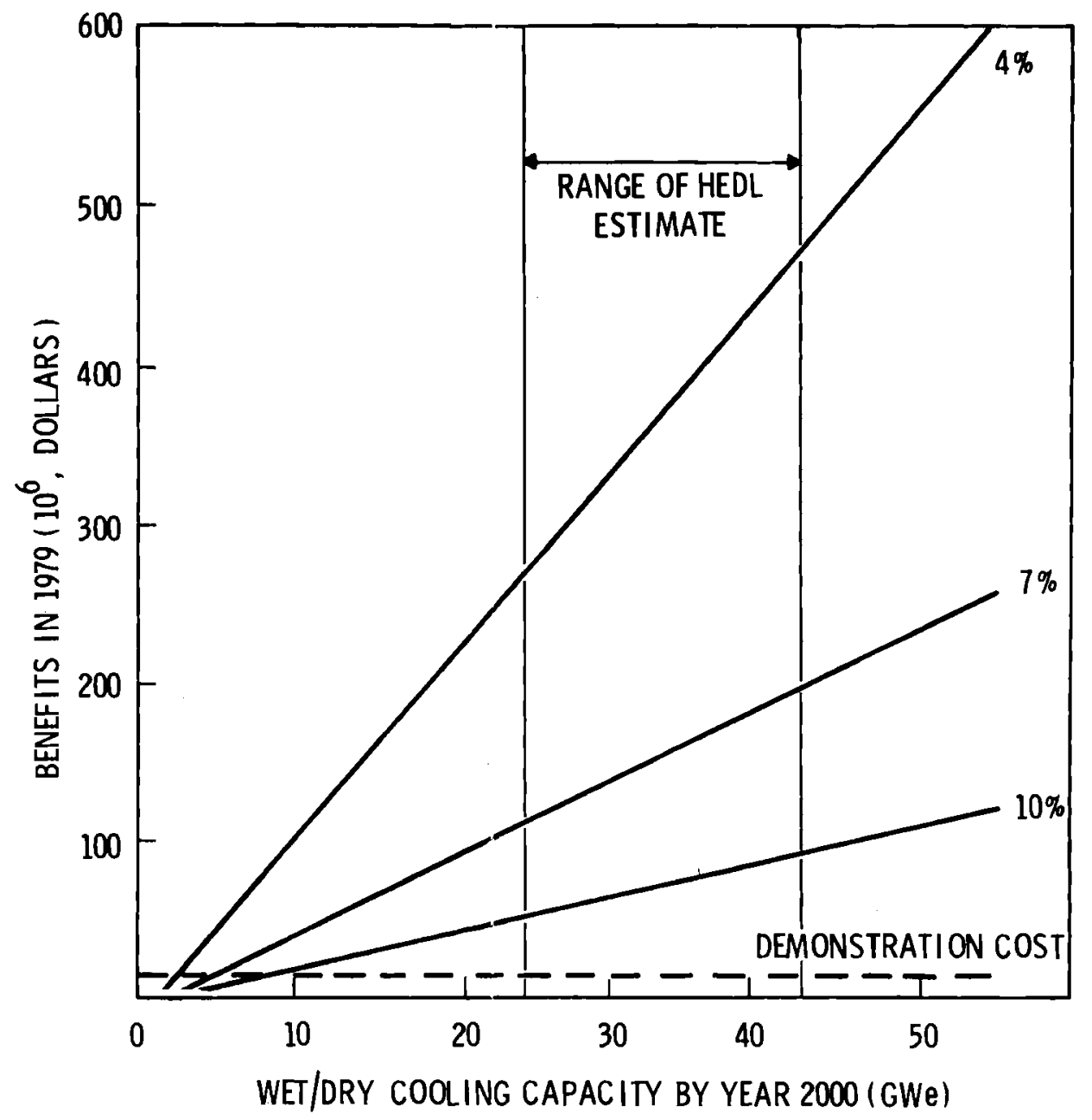

FIGURE B-2. Case II, 20 Percent Wet 


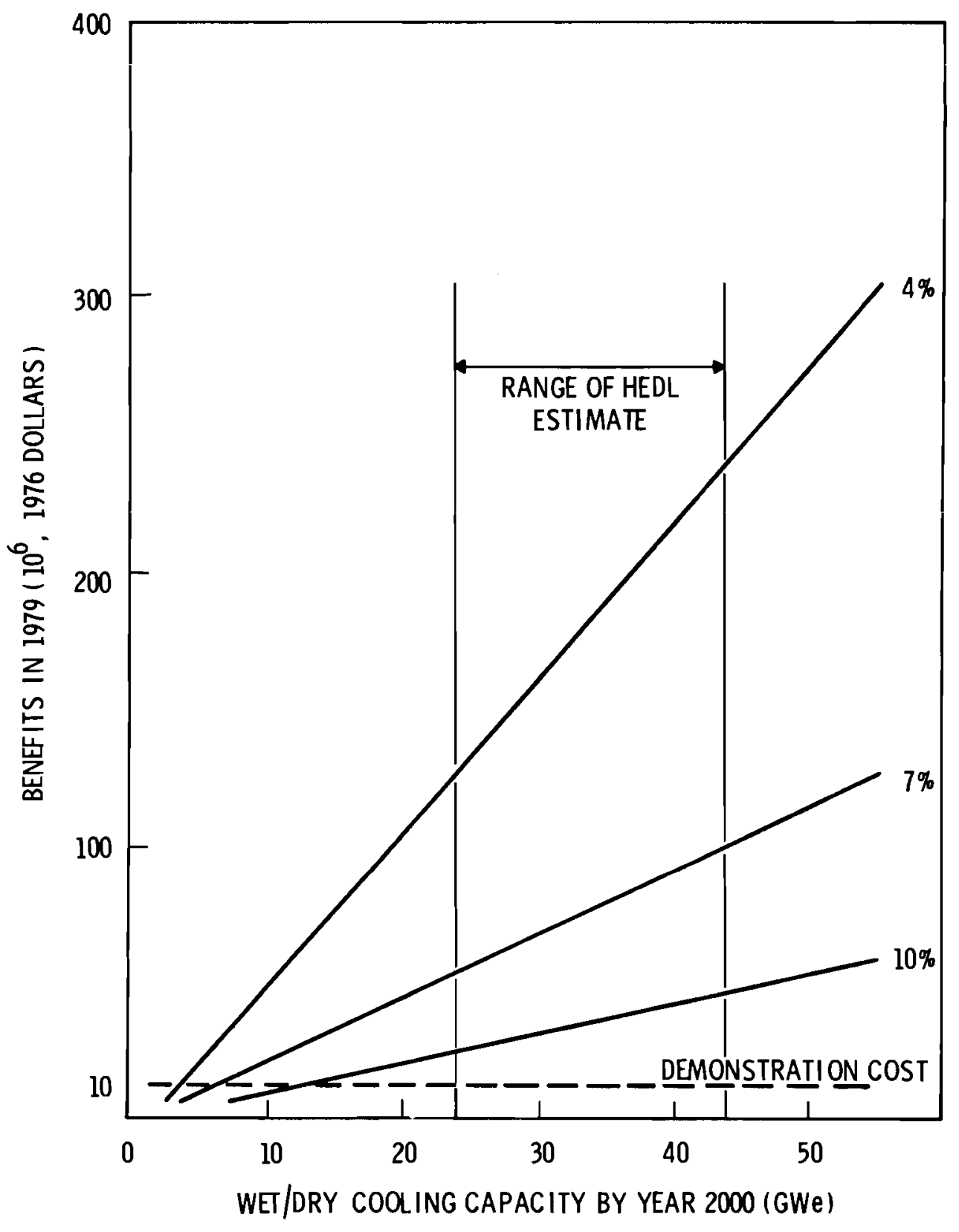

FIGURE B-3. Case III, 20 Percent Wet, $Z=0.7$ 


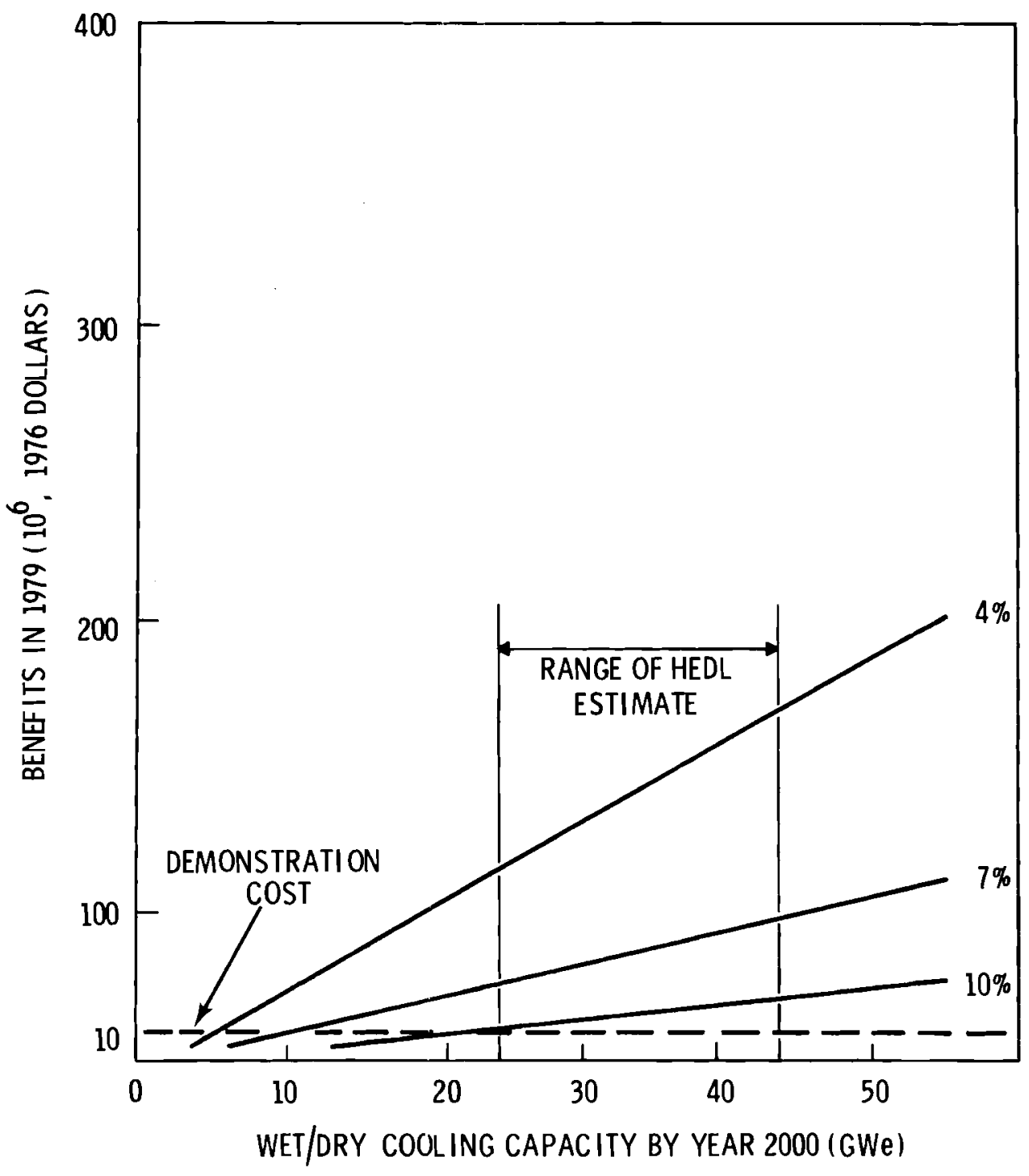

FIGURE B-4. Case III, 20 Percent Wet, $Z=0.85$ 


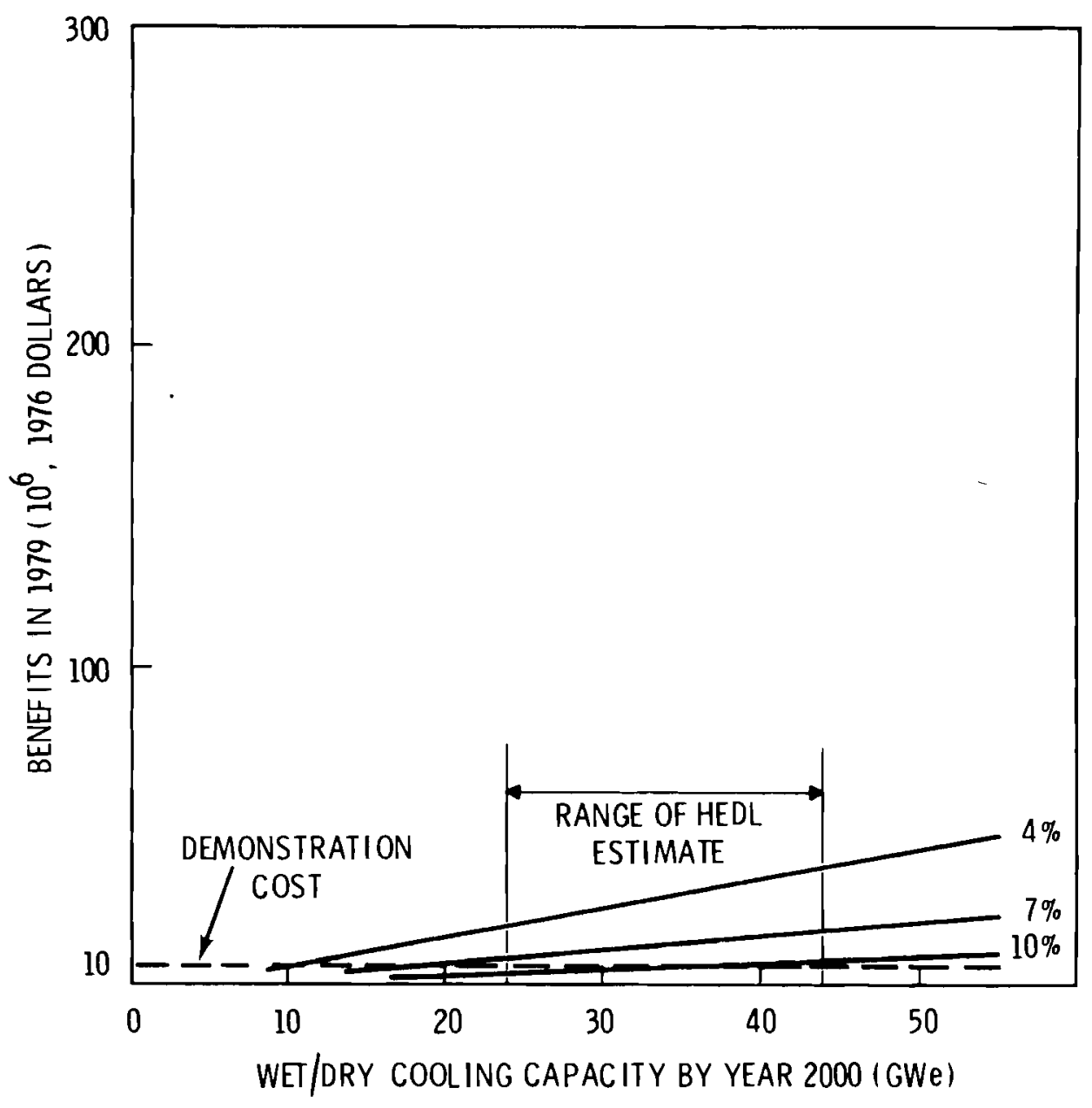

FIGURE B-5. Case III, 20 Percent Wet, $Z=0.95$ 


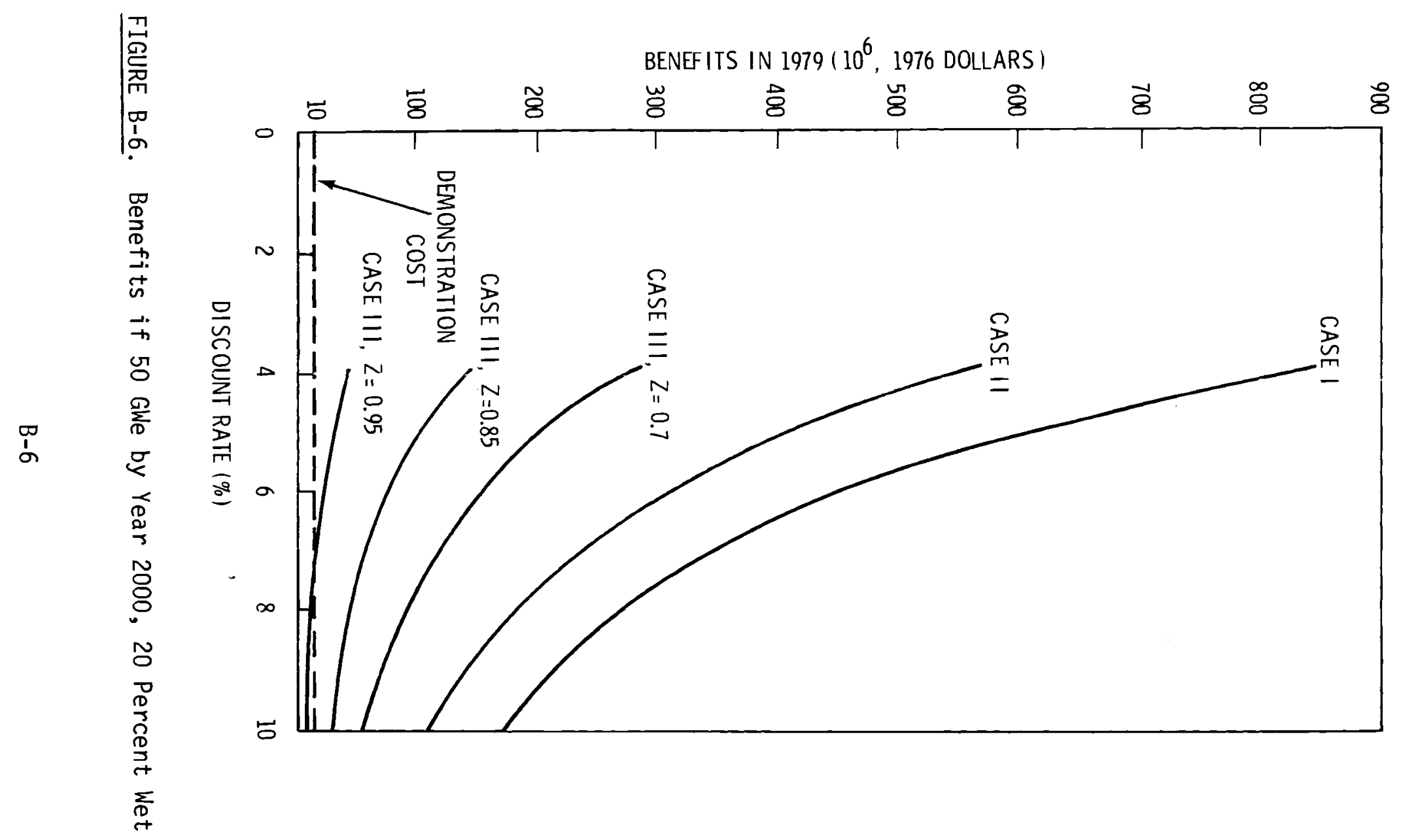




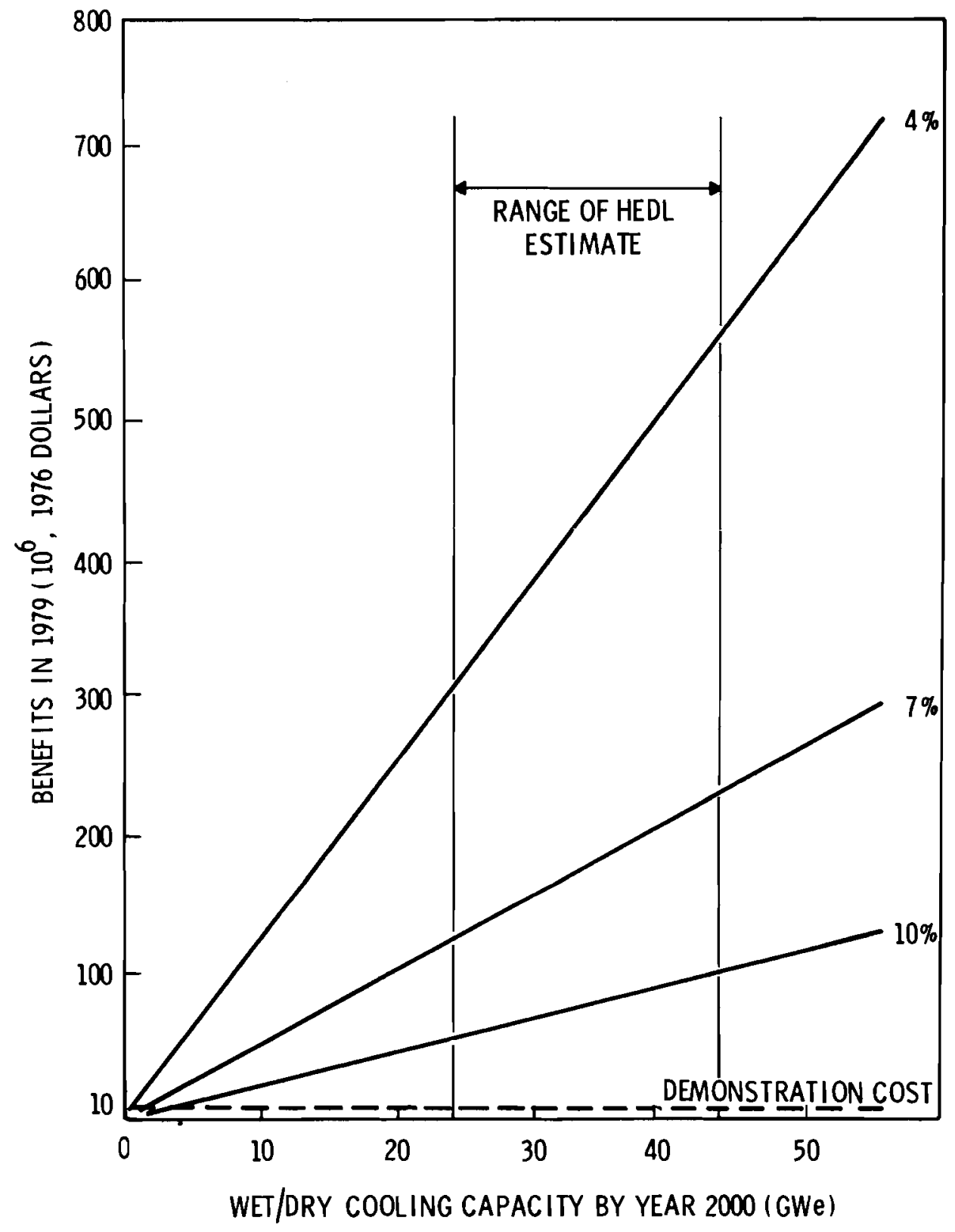

FIGURE B-7. Case I, 50 Percent Wet 


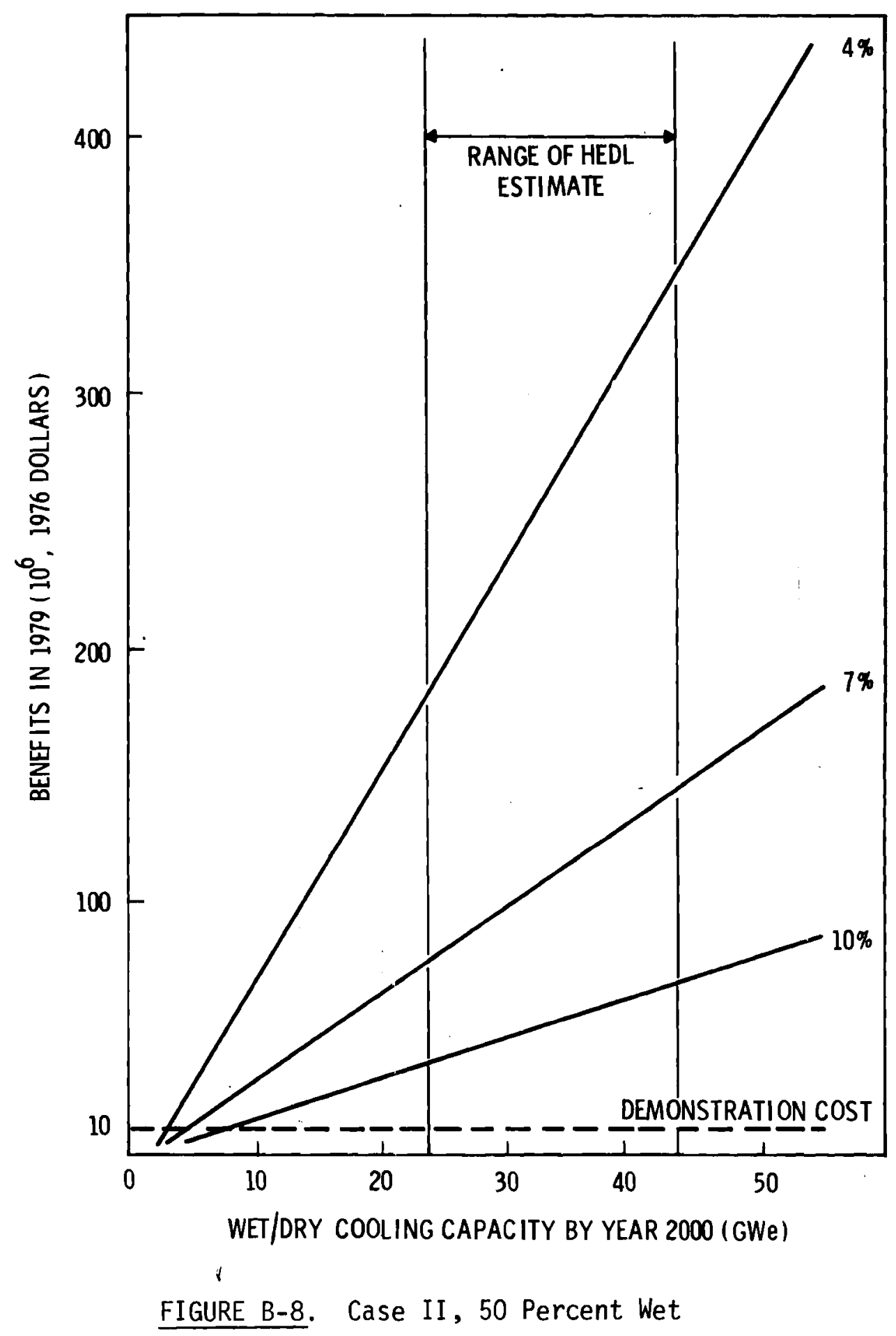




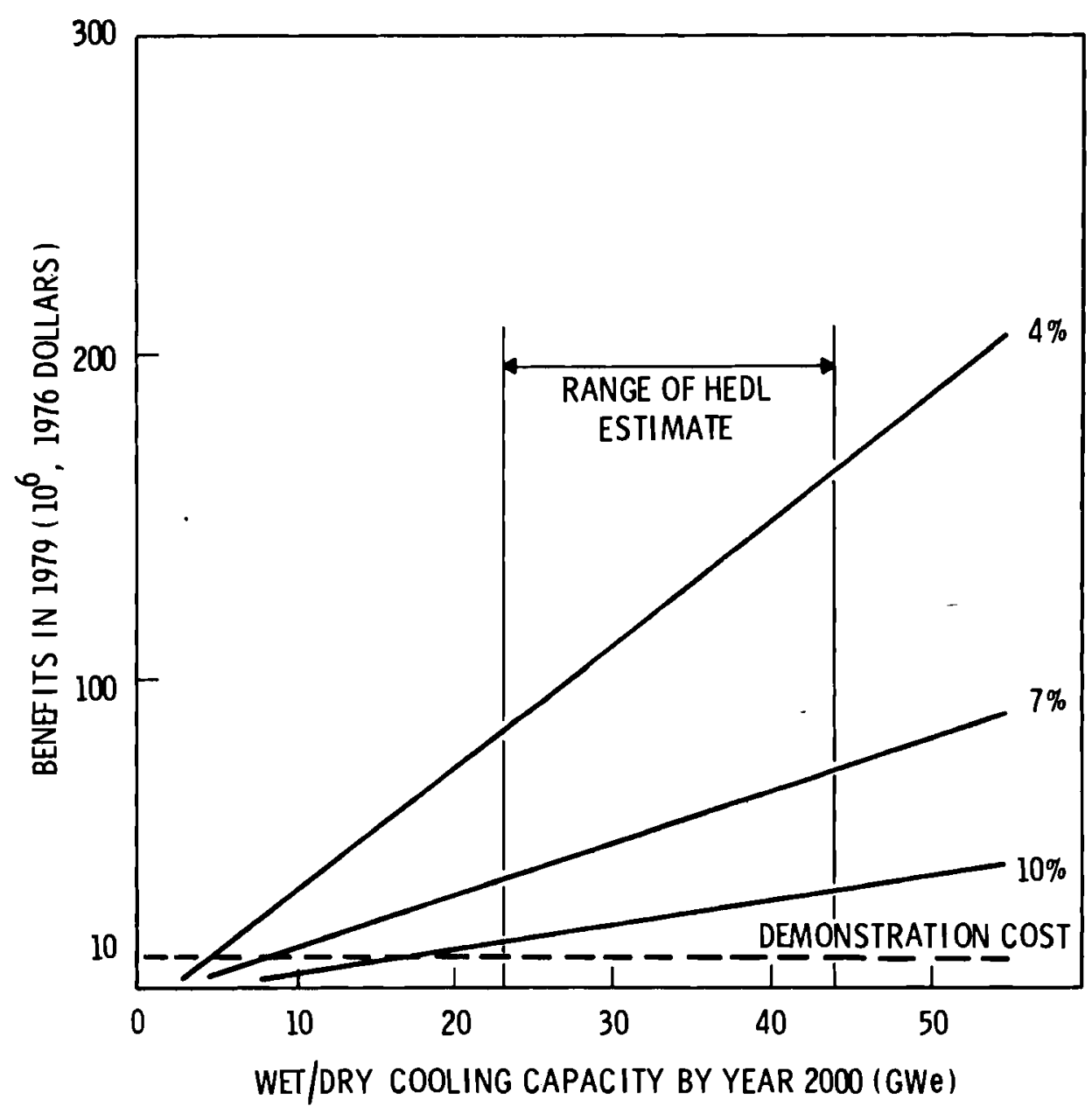

FIGURE B-9. Case III, 50 Percent Wet, $Z=0.7$ 


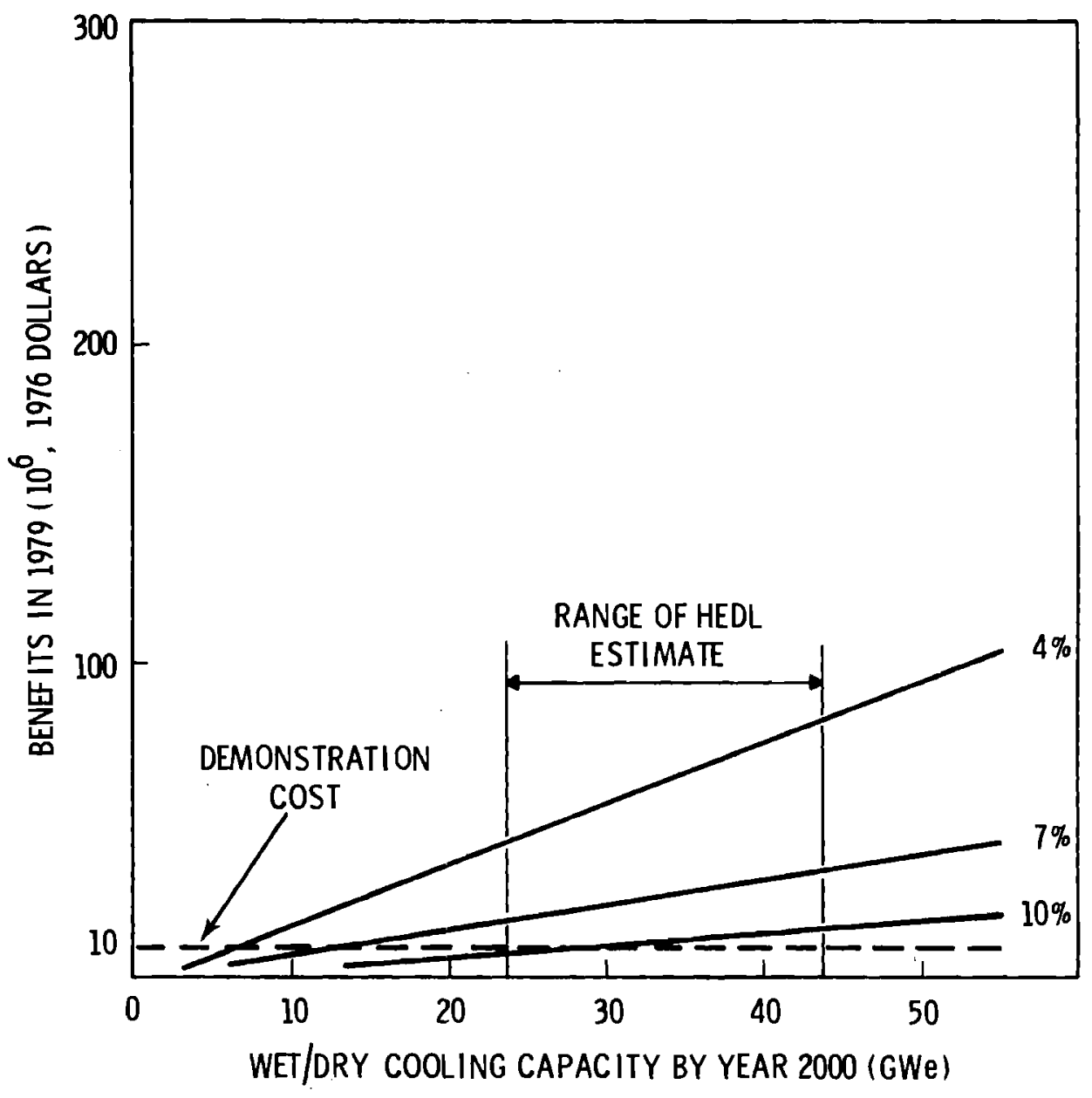

FIGURE B-10. Case III, 50 Percent Wet, $Z=0.85$ 


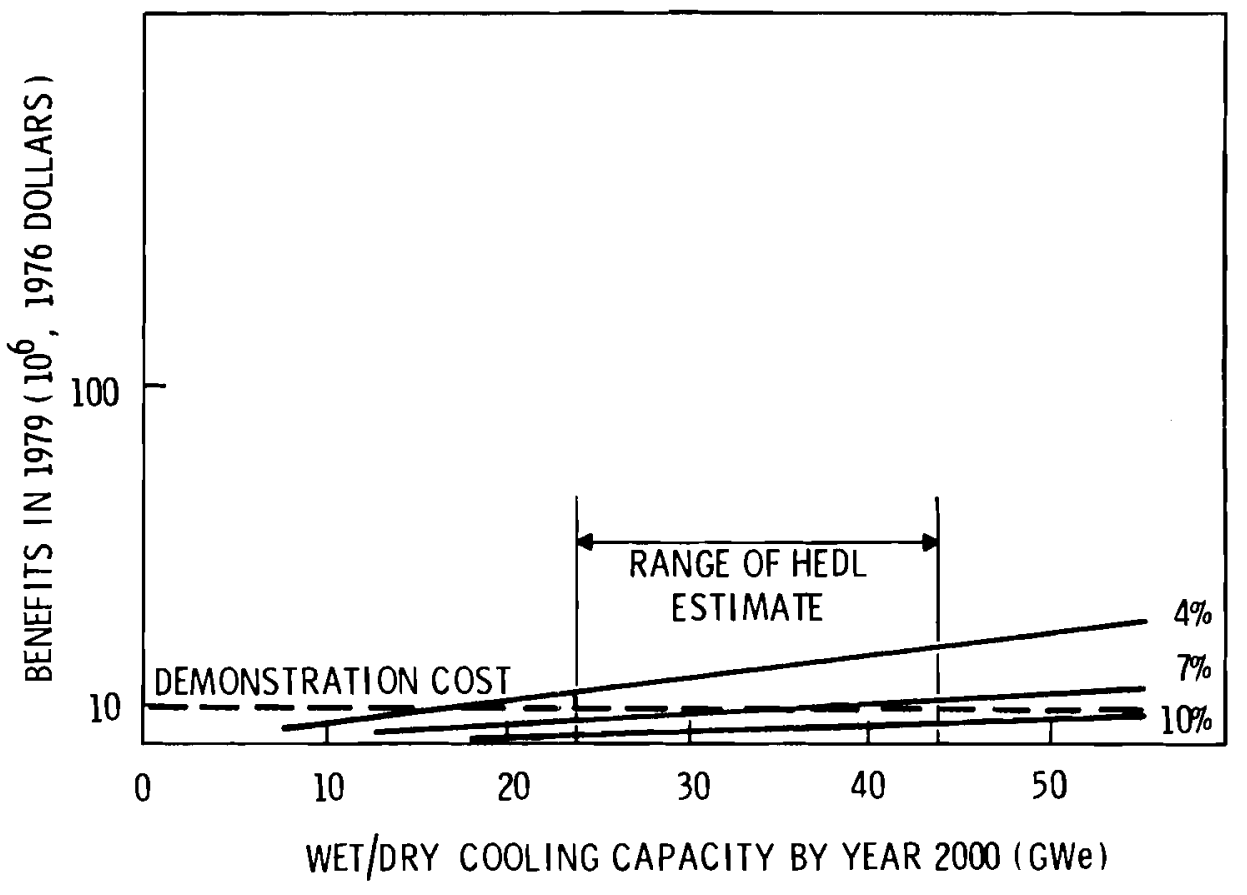

FIGURE B-11. Case III, 50 Percent wet, $Z=0.95$ 


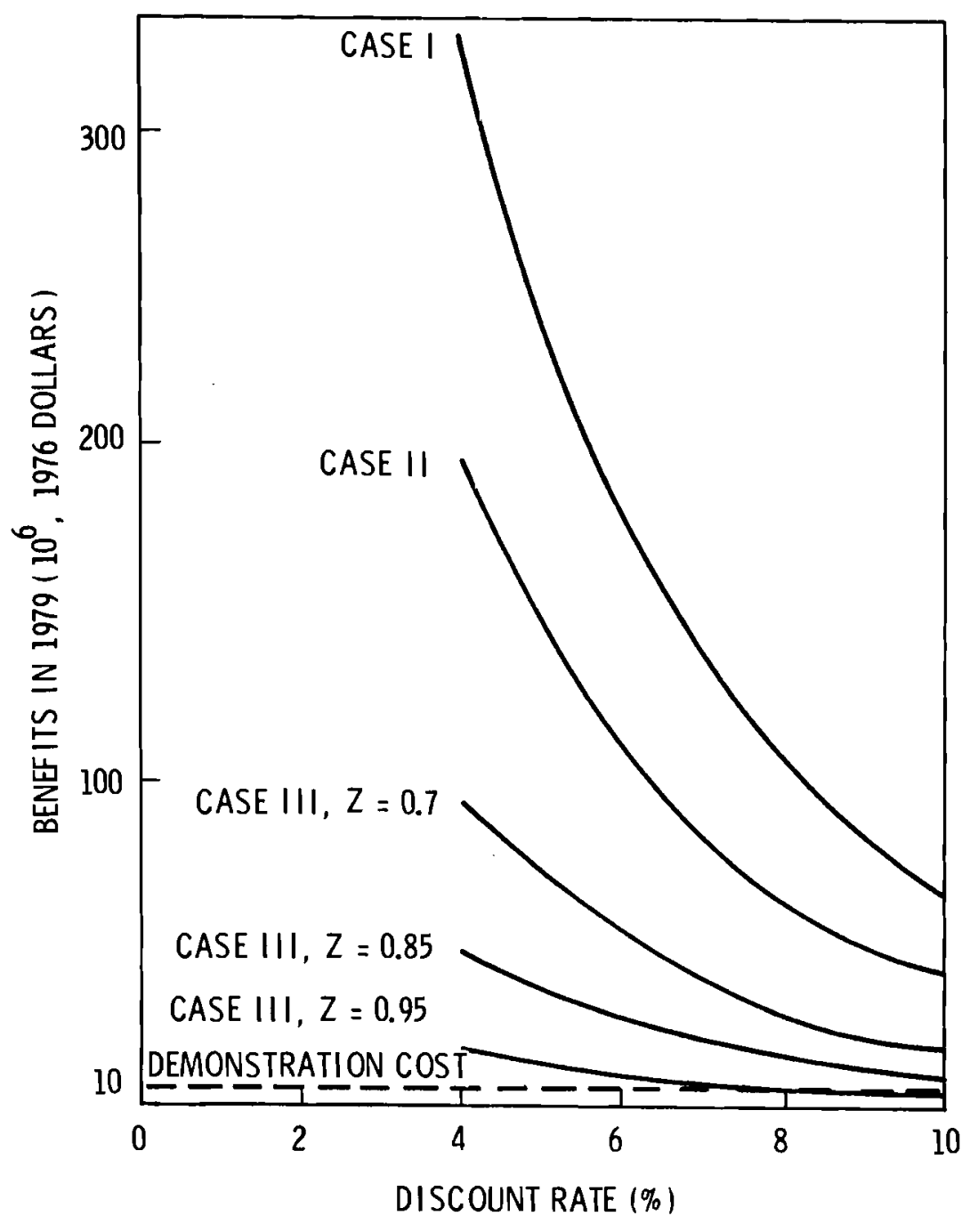

FIGURE B-12. Benefits if 50 GWe by Year 2000, 50 Percent Wet 


\section{DISTRIBUTION}

No. of

Copies

OFFSITE

Energy Research and Development Administration

A. A. Churm

Chicago Patent Group

9800 South Cass Avenue

Argonne, IL 60439

Energy Research and Development Administration Office of Assistant General Counsel for Patents Washington, DC 20545

27 ERDA Technical Information Center

Energy Research and Development Administration

I. Helms

Advanced Concepts Evaluation Branch - F-309

Division of Nuclear Research and Application Washington, DC 20545

Energy Research and Development Administration

W. F. Savage

Chief, Advanced Concepts Evaluation Branch

Division of Nuclear Research and Application Washington, DC 20545

Energy Research and Development Administration

D. C. Bauer

Director, Division of Nuclear Research and Application Washington, DC 20545

10 Energy Research and Development Administration

R. B. Morrow

Special Projects Branch

Division of Nuclear

Research and Application Washington, DC 20545
No. of

Copies

Energy Research and

Development Administration

N. Gerstein

Chief, Special Projects Branch

Division of Nuclear

Research and Application

Washington, DC 20545

Energy Research and Development Administration

W. E. Mott

Director, Energy Control Technology

Division of Biomedical and

Environmental Research

Washington, DC 20545

Energy Research and

Development Administration

G. A. Newby

Assistant Director

Division of Nuclear Research

and Application

Washington, DC 20545

Allied Chemical Company

B. R. Dickey

550 2nd Street

Idaho Falls, ID 83401

Allis-Chalmers Power Systems, Inc.

J. S. Joyce

1135 South 70th Street

West Allis, WI 53214

Aluminum Company of America

E. T. Wanderer

Alcoa Technical Center

Alcoa Center, OH 45069

American Electric Power

H. J. Janzon

2 Broadway

New York, NY 10004

Arizona Public Service Co.

T. Woods

2121 W. Cheryl Drive

Phoenix, AZ 85021 
No. of

Copies

Babcock \& Wilcox

M. W. Peterson

Fossil Power Division

20 South Van Buren

Barberton, $\mathrm{OH} 44203$

Baltimore Aircoil Co., Inc.

E. Schinner

P.0. Box 7322

Baltimore, MD 21227

Baltimore Gas \& Electric Co.

G. C. Creel

Gas \& Electric Building

Baltimore, MD 21203

Battelle-Geneva

J. P. Budliger

7 Route De Drizi

1227 Geneva, SWITZERLAND

Bechtel Corporation

$P$. Leung

P.0. Box 60860

Terminal Annex

Los Angeles, CA 90060

Bechtel Corporation

G. R. Retti

P.0. Box 3965

San Francisco, CA 94119

R. W. Beck and Associates

J. P. Rossie

400 Prudential Plaza

Denver, CO 80202

Black Hills Power and Light Company

B. Westre

P.0. Box 1400

Rapid City, SD 57701

California State Energy Resources Conservation

and Development Commission

L. E. Stamets

1111 Howe Avenue

Sacramento, CA 95825
No. of

Copies

Carolina Power \& Light Co. J. Sell

336 Fayettesville Street

Raleigh, NC 27602

Catalytic Construction Corp.

J. Morse

P.0. Box 11402

Charlotte, NC 28029

Combustion Engineering

H. H. Osborn

Air Preheater Company

Wellsville, NY 14895

Commonwealth Edison

R. H. Holyoak

One First Plaza

P.0. Box 767

Chicago, IL 60690

Consolidated Edison Co. of New York, Inc.

W. A. Messner

4 Irving Place

New York, NY 10003

Consolidated Edison Co. of New York, Inc.

C. L. Newman

4 Irving Place

New York, NY 10003

Cornel1 University

F. K. Moore

Ithaca, NY 14850

Curtiss-Wright Corporation

R. J. Haberski

One Passaic Street

Wood Ridge, NJ 07075

Duke Power Company

S. K. Blackley

P.0. Box 2178

Charlotte, NC 28201

Dynatech Company

E. Guyer

99 Erie Street

Cambridge, MA 02139 
No. of

Copies

Ecodyne Cooling Products Co.

J. K. Swindt

Santa Rosa, CA 95403

Electric Power Research Institute

J. Maulbetsch

$3412 \mathrm{Hillview} \mathrm{Avenue}$

P.0. Box 10412

Palo Alto, CA 94304

Environmental Protection Agency

M. Maxwe11 (MD-61)

IERL-RTP

Research Triangle Park, NC 27711

Environmental Protection Agency

F. H. Rainwater

Pacific Northwest Water Laboratory

200 S.W. 35th Street

Corvalitis, OR 97330

Environmental Sciences and Services

W. Hoydisch

44-33 37th Street

Long Is land City, NY 11101

Exxon Research Center

J. G. Stevens

B1 dg. 1, Rm. 2048

P.0. Box 8

Linden, NJ 07036

Foster Wheeler Energy Co.

E. L. Damon

110 S. Orange Avenue

Livingston, NJ 07039

Franklin Institute

A. M. Rubin

Twentieth \& Parkway

Philadelphia, PA 19103
No. of

Copies

GEA Airexchangers, Inc.

B. Davis

46 Worthington Drive

Maryland Heights, MD 63043

General Atomic Company

A. C. Eulberg

P.0. Box 81608

San Diego, CA 92138

General Electric Co.

E. H. Miller

Large Steam Turbine Division

300 Nott Street

Schenectady, NY 12301

General Motors Corp.

R. K. Shah

Harrison Radiator Division

Lockport, NY 14094

Gilbert Associates, Inc.

J. F. Sebald

525 Lancaster Avenue

Reading, PA 19603

Heat Transfer Research Inc.

J. E. Taboric

1000 S. Fremont Avenue

Alhambra, CA 91802

Hudson Products

M. W. Larinoff

6855 Horwin Drive

Houston, TX 77036

Hudson Products

E. C. Smith

6855 Horwin Drive

Houston, TX 77036 
No. of

Copies

Ingersol 1-Rand

W. R. Scott, Jr.

Phillipsburg, NJ 08865

Italimpianti - Societa Ital iana Impianti p.a.

C. Rocco

Piazza, Piccapietra 9

18121 Genoa, ITALY

Los Angeles Department of Water and Power

J. L. Mulloy

111 N. Hope Street

Los Angeles, CA 90012

Louisiana Power \& Light Co.

R. J. Meyer

142 Delaronde Street

New Orleans, LA 70174

The Charles T. Main Co.

E. S. Miliaras

Southeast Tower

Prudential Center

Boston, MA 02199

The Marley Co.

R. Landon

5800 Fox Ridge Drive

Mission, KS 66202

Massachusetts Institute of

Technology

L. R. Gl icksman

77 Massachusetts Avenue

Cambridge, MA 02139

Massachusetts Institute of Technology

M. W. Golay

77 Massachusetts Avenue

Cambridge, MA 02139

Massachusetts Institute of

Technology

R. Harleman

Department of Civil Engineering

77 Massachusetts Avenue

Cambridge, MA 02139
No. of

Copies

McDonnell Douglas Astronautics Co. S. O'Hare

5301 Bolsa Avenue

Huntington Beach, CA 92647

Montana Power Co.

R. Hofacher

40 E. Broadway

Butte, MT 59701

New York University

W. G. Hoydysn

University Heights

New York, NY 10453

Niagara Blower

W. Kals

405 Lexington Avenue

New York, NY 10017

Northeast Utilities

R. H. Meyer

P.0. Box 270

Hartford, CT 06101

Oak Ridge National Laboratory

J. W. Michel

OTEC Heat Exchange Project Activity

Box Y

Oak Ridge, TN 37830

Oregon State University

L. P. Davis

Department of Mechanical

Engineering

Corvallis, OR 97330

Oregon State University

C. E. Wicks

Department of Chemical

Engineering

Corvallis, OR 97330

Oregon State University

J. G. Knudson

Engineering Experiment Station

Corvallis, OR 97330 
No. of

Copies

Pacific Gas \& Electric

A. A. Ariey

77 Beale Street

San Francisco, CA 94106

Pacific Gas \& Electric

F. F. Mautz

77 Beale Street

San Francisco, CA 94106

Pacific Power \& Light Co.

$P$. G. Humphries

Publ ic Service Bldg.

Portland, OR 97204

Pennsylvania Power \& Light

D. G. Pfeiffer

2 North Ninth Street

Allentown, PA 18101

PFR Engineering Systems, Inc.

T. Rozenmann

Suite 832

4676 Admiralty Way

Marina del Rey, CA 90291

Prof. Ing. Carlo Roma

Piazza delle Muse 8

Rome, ITALY

Power Generation Cooling Systems

G. L. Henderson

4714 - 52nd Street S.

Seattle, WA 98118

Public Service of Colorado

R. F. Walker

5900 E. 39th Avenue

Denver, CO 80207

Public Service of New Mexico

J. D. Maddox

Corporate Planning Dept.

A1buquerque, NM 87103
No. of

Copies

Research Cottrell

G. E. Collins

Hamon Cooling Tower Division

Box 750

Bound Brook, NJ 08805

Reynolds Aluminum Co.

R. Lindberg

Reynolds Metallurgical

Research Laboratory

Richmond, VA 23261

San Diego Gas \& Electric

R. G. Lacy

101 Ash Street

San Diego, CA 92107

Seattle City Light

R. L. Skone

1015 Third Ave.

Seattle, WA 98104

Southern California Edison

F. A. McCracken

2244 Walnut Grove Avenue

Rosemead, CA 91770

P. Sporn

Consultant Engineer

74 Trinity $\mathrm{Pl}$., Suite 511

New York, NY 10006

Stanford University

A. L. London

Department of Mechanical

Engineering

Stanford, CA 94305

Stearns and Rogers

J. Y. Parce

700 S. Ash Street

Denver, CO 80222

Stone \& Webster Engineering Corp.

D. H. Guild

225 Frankl in Street

Boston, MA 02107 
No. of

Copies

Tampa Electric Co.

H. I. Wilson

P.0. Box 111

Tampa, FL 33601

Texas Electric Service Co. $W$. Keel

115 W. Seventh Street

Fort Worth, TX 76102

Tucson Gas \& Electric

A. A. Ward

220 W. 6th Street

Tucson, AZ 85701

Union Carbide Corp.

J. Bartz

Linde Division

61 East Park Drive

Tonawanda, NY 14150

Union Carbide Corp.

G. J. Kidd

ORGDP - K-25

P.0. Box D

Oak Ridge, TN 37803

Union Carbide Corp.

$F$. Notaro

Linde Division

61 East Park Drive

Tonawanda, NY 14150

United Engineers \& Constructors

G. A. Englesson

1401 Arch Street

Philadelphia, PA 19105

University of Bremen

K. Simhan

Bremen, WEST GERMANY

University of Iowa

J. F. Kennedy

Hydraulic Research Institute

Iowa City, IA 52240
No. of

Copies

University of Kentucky

$T$. E. Eaton

Mechanical Engineering

Department

Lexington, KY 40506

Utah Power \& Light

J. H. Hutchinson

1407 W. N. Temple

Salt Lake City, UT 84103

Virginia Electric \& Power Co.

S. Ragone

700 E. Franklin Street

Richmond, VA 23261

Washington State University

J. T. Kimbal 1

College of Engineering

Pullman, WA 99163

Washington Water Power Co.

D. L. 01 son

E. 1411 Mission Avenue

Spokane, WA 99202

West Associates

G. H. Soule

Sierra Pacific Power Co.

100 E. Moana Lane

Reno, NV 89510

Western States Water Council

J. A. Barnett

Executive Director

220 South 2nd East

Suite 200

Salt Lake City, UT 84111

Westinghouse Electric Corp.

G. J. Silvestri

Steam Turbines Division - G108

Lester Branch

Box 9175

Philadelphia, PA 19113 
No. of

Copies

Westinghouse Electric Corp.

K. A. 01eson

Steam Turbines Division - G108

Lester Branch

Box 9175

Philadelphia, PA 19113

L. E. Wilkinson

Consultant

6582 Ganon Street, S.E.

Salem, OR 97301

\section{ONSITE}

ERDA Richland Operations Office

Energy Programs Division

H. E. Ransom

Westinghouse Hanford Company Hanford Engineering Development Laboratory

\section{J. Fletcher}

93 Battelle-Northwest
R. T. Al lemann
D. J. Braun
J. W. Currie (20)
D. E. Deonigi
R. L. Dillon
D. W. Dragnich
R. L. Drake
D. W. Faletti
J. W. Finnigan
T. J. Foley
B. C. Fryer
J. D. Goodenough
J. J. Hauth
A. J. Haverfield
C. H. Henager
A. B. Johnson
W. S. Kelly
R. S. Kemper
C. J. Knoll
W. V. Loscutoff

No. of

Copies

Battelle-Northwest (cont)
R. P. Marshall
D. E. Olesen
Y. Onishi

H. L. Parry

L. T. Pederson

H. C. Riches

J. R. Sheff

G. C. Smith

J. S. Stoakes

A. M. Sutey

R. D. Tokarz

D. S. Trent

1. Vagins

R. A. Waiter

R. L. Watts

R. D. Widrig

L. E. Wiles

F. R. Zaloudek

File - B. M. Johnson (30)

Technical Information (5)

Technical Publications 
$r$

. 